\title{
The role of tight junction proteins in ovarian follicular development and ovarian cancer
}

\author{
Lingna Zhang ${ }^{1, *}$, Tao Feng ${ }^{2}$ and Leon J Spicer ${ }^{1}$ \\ ${ }^{1}$ Department of Animal Science, Oklahoma State University, Stillwater, Oklahoma, USA and ${ }^{2}$ Institute of Animal \\ Husbandry and Veterinary Medicine, Beijing Academy of Agriculture and Forestry Sciences, Beijing, China
}

Correspondence should be addressed to L J Spicer; Email: leon.spicer@okstate.edu

*(L Zhang is now at Department of Animal and Food Sciences, Texas Tech University, Lubbock, Texas, USA)

\begin{abstract}
Tight junctions (TJ) are protein structures that control the transport of water, ions and macromolecules across cell layers. Functions of the transmembrane TJ protein, occluding (OCLN) and the cytoplasmic TJ proteins, tight junction protein 1 (TJP1; also known as zona occludens protein-1), cingulin (CGN) and claudins (CLDN) are reviewed, and current evidence of their role in the ovarian function is reviewed. Abundance of $O C L N, C L D N s$ and TJP1 mRNA changed during follicular growth. In vitro treatment with various growth factors known to affect ovarian folliculogenesis indicated that CGN, OCLN and TJP1 are hormonally regulated. The summarized studies indicate that expression of TJ proteins (i.e., OCLN, CLDN, TJP1 and CGN) changes with follicle size in a variety of vertebrate species but whether these changes in $\mathrm{TJ}$ proteins are increased or decreased depends on species and cell type. Evidence indicates that autocrine, paracrine and endocrine regulators, such as fibroblast growth factor-9, epidermal growth factor, androgens, tumor necrosis factor- $\alpha$ and glucocorticoids may modulate these TJ proteins. Additional evidence presented indicates that TJ proteins may be involved in ovarian cancer development in addition to normal follicular and luteal development. A model is proposed suggesting that hormonal downregulation of TJ proteins during ovarian follicular development could reduce barrier function (i.e., selective permeability of molecules between theca and granulosa cells) and allow for an increase in the volume of follicular fluid as well as allow additional serum factors into the follicle that may directly impact granulosa cell functions.

Reproduction (2018) 155 R183-R198
\end{abstract}

\section{Introduction}

Follicular development is a coordinated series of events regulated by endocrine feedback systems of the hypothalamus-pituitary-gonad axis and is fine-tuned by autocrine and paracrine communication signals within follicular cells of the ovary involving the maturation of the oocyte, proliferation and differentiation of granulosa cells (GC) and theca cells (TC) (Richards 1980, Buccione et al. 1990, Hsueh et al. 2015). In cattle, increased folliclestimulating hormone $(\mathrm{FSH})$ recruits waves of small antral follicles (Fortune et al. 1990, Mihm \& Bleach 2003, Spicer 2004) and maintains their survival (Silva et al. 2006). During development, the follicular antrum will enlarge and form the microenvironment for further maturation of the oocyte and follicular cells (Fahiminiya \& Gerard 2010, Hsueh et al. 2015). This review will evaluate the current knowledge on tight junctions (TJ) and their associated proteins in follicular development. Because little is known about the function of TJ proteins in the ovary, evidence highlighting function of these TJ proteins is reviewed in the subsequent sections.

Epithelial cells usually develop specified adhesive structures to allow the communication and interaction with each other and to control paracellular permeability. $\mathrm{TJ}$, adherens junctions (AJ) and desmosomes form the apical junctional complex and are abundantly expressed in epithelial and endothelial cells to provide cell-cell contacts and seal the paracellular space of the cell layer (Paris \& Bazzoni 2008, Van Itallie \& Anderson 2014). Among all the three junctional complexes, only TJ control the paracellular permeability for ions, water and other molecules (Balda et al. 1996, Suzuki 2013). TJ also help maintain the cell polarity by restricting the diffusion of the membrane components between apical and basolateral areas (Cereijido et al. 2008, Paris \& Bazzoni 2008). In addition to ovarian follicular cells (Mora et al. 2012, Zhang et al. 2017), TJ have been characterized in primate fibroblasts (Raviola et al. 1987, Van Itallie \& Anderson 1997, Furuse et al. 1998), mouse Sertoli cells (Morita et al. 1999) and mouse embryonic brain neurons (Bauer et al. 1999). Desmosomes are a type of intercellular junctions that provide strong adhesion between cells and are made of several proteins including cadherins, desmoglein and desmocollin (Owen \& Stokes 2010, Hatzfeld et al. 2017). AJ are a type of adhesive junctions also involving cadherins and 
are common in epithelial cells (Yap et al. 2015, Rübsam et al. 2017).

Besides the classic barrier and fence functions, emerging studies show that TJ act as signaling complexes, mediating the exchange of the information from inside and outside the cells to regulate its own assembly and protein expression and to control intracellular gene expression and subsequent cellular responses such as proliferation and differentiation (Bordin et al. 2004, Balda \& Matter 2009). TJ contains integral membrane proteins (e.g., claudins $(C L D N)$, occludin $(\mathrm{OCLN})$, junctional adhesion molecules (JAMs)) that interact with the same proteins of the adjacent cells to control the barrier functions (Citi 1993, Balda et al. 1996, Bamforth et al. 1999). Intracellular adaptor/scaffold proteins (e.g., tight junction proteins (TJP)/zonula occludens (ZO), cingulin (CGN)) stabilize the TJ strands by linking the TJ membrane proteins to the cytoskeleton structures (e.g., actin, myosin) and regulate gene expression and subsequent cellular responses, such as proliferation and differentiation by recruiting key modulators of certain intracellular signaling pathways (Balda \& Matter 2000, Balda et al. 2003, Citi et al. 2012). For example, tumorigenesis is accompanied by disrupted TJ structure, decreased expression of TJ proteins, loss of differentiation and increased proliferation and migration (Rachow et al. 2013). Gap junctions differ from TJ in that gap junctions mediate the intercellular communication by forming highly regulated channels connecting the cytoplasm of two adjacent cells to allow direct exchange of small diffusible molecules between cells (Hervé et al. 2007, Yeager \& Harris 2007), and in particular, between the oocyte and cumulus cells within the follicle (Eppig et al. 1997, Winterhager \& Kidder 2015). The integral membrane proteins that form gap junctions include over 20-member connexin family proteins (Evans 2015). The subsequent sections of this review will first describe these TJ proteins and later describe how they may be involved in ovarian function.

\section{TJ proteins \\ Occludin (OCLN)}

The firstTJ protein identified, OCLN, is localized at TJ and is a highly conserved (e.g., $90 \%$ amino acid homology between human and bovine; 59-68 kDa molecular weight) 4-transmembrane protein with different domains responsible for various biological functions (Furuse et al. 1993). The $\mathrm{N}$-terminus and extracellular regions are essential to provide TJ with sealing/barrier properties, as mutants cause increased TJ permeability (Wong \& Gumbiner 1997) and gaps in the P-face-associated TJ strands (Bamforth et al. 1999). The extracellular loops, especially the second loop, are essential for the stable assembly of OCLN in TJ (Medina et al. 2000). Transmembrane domains are crucial for maintaining selective paracellular permeability of canine kidney epithelial (MDCK) cells (McNeil et al. 2006) by connecting and cooperating with claudins, especially CLDN4 (Balda \& Matter 2000). The COOH-terminal domain of OCLN in the cytoplasm is essential for the correct assembly and barrier function of TJ (Chen et al. 1997), recruitment of OCLN to TJ (Balda et al. 1996) and the direct association of OCLN and many other peripheral membrane molecules, such as TJP1 and actin cytoskeleton (Furuse et al. 1994, Wittchen et al. 1999), and CGN (Cordenonsi et al. 1999). Expression of C-terminal mutated or normal OCLN in MDCK cells results in increased paracellular flux of small size tracers (Balda et al. 1996, 2000). Also, OCLN-knockout mice (Table 1) show normal barrier function and transepithelial resistance in epithelia of different organs (e.g., colon, stomach, urinary bladder) (Schulzke et al. 2005), but exhibit histological abnormalities in several tissues (e.g., intestinal epithelium), postnatal growth retardation and reproductive defects (Saitou et al. 2000). Increased OCLN expression is linked to increased tight epithelia (González-Mariscal et al. 2000) and increased transepithelial resistance (Balda et al. 1996, McCarthy et al. 1996). Using knockdown techniques, a study showed in vivo (mouse intestine) and in vitro (human Caco-2 monolayers) that OCLN was important for limiting macromolecule $(10-70 \mathrm{kDa})$ flux across the epithelia without effecting transepithelial resistance (Al-Sadi et al. 2011) and increased TJ permeability to monovalent and divalent inorganic cations in MDCK cells (Table 1; Yu et al. 2005). Cell adhesion and apoptosis are also regulated by OCLN. For example, expression of OCLN in rat kidney fibroblasts confers cells with adhesiveness (Van Itallie \& Anderson 1997) and forced expression of OCLN in human cutaneous squamous carcinoma cells (Rachow et al. 2013) and in human cervical carcinoma cells (Osanai et al. 2006) increases the sensitivity of the cells to different apoptogenic factors. Also, downregulation of OCLN in human keratinocytes results in reduced cell-cell adhesion (Rachow et al. 2013) and is a frequent observation in various tumors (Tobioka et al. 2004, Osanai et al. 2006, Orbán et al. 2008, Martin et al. 2010). The role of OCLN in ovarian function and cancer is just beginning to unfold and will be discussed in a later section.

\section{TJPs/ZOs}

TJPs/ZOs are members of the membrane-associated guanylate kinase (MAGUK) homologue family, characterized by a motif containing conserved proteinbinding domains (one or more post-synaptic density protein 96 (PSD-96)/discs large-1 (Dlg)/ZO-1 (PDZ) domains, a Src-homology-3 (SH3) domain and a guanylate kinase (GUK) domain) (Fanning et al. 2002, Funke et al. 2005). Three ZOs (ZO-1, ZO-2 and ZO-3; 
Table 1 CLDN, CGN, OCLN and TJP gene knockout/knockdown models and their phenotypes.

\begin{tabular}{|c|c|c|c|c|}
\hline Gene $^{a}$ & Knockout/knockdown & Species & Phenotype & References \\
\hline CLDN1 & Knockout & Mouse & $\begin{array}{l}\text { Death after birth with transdermal } \\
\text { dehydration }\end{array}$ & $\begin{array}{l}\text { Furuse et al. (2002), } \\
\quad \text { Sugawara et al. (2013) }\end{array}$ \\
\hline CLDN2 & Knockout & Canine kidney cells & $\begin{array}{l}\text { Increasing transepithelial electrical } \\
\text { resistance (TER) in MDCK II cells }\end{array}$ & Tokuda and Furuse (2015) \\
\hline CLDN2 & Knockdown & $\begin{array}{l}\text { Human adenocarcinoma A549 } \\
\text { cells }\end{array}$ & Decreasing cell migration concomitant & Ikari et al. (2011) \\
\hline CLDN3 & Knockdown & Mouse & Inhibition the growth of ovarian tumors & (Sun et al. (2011) \\
\hline CLDN4 & Knockout & Mouse & Increased postnatal lung injury & Kage et al. (2014) \\
\hline CLDN5 & Knockout & Mouse & $\begin{array}{l}\text { Death after birth with a defective blood } \\
\text { brain barrier function }\end{array}$ & Nitta et al. (2003) \\
\hline CLDN6 & Knockdown & Xenopus & Pronephros dysfunction & Sun et al. (2015) \\
\hline CLDN7 & Knockout & Mouse & $\begin{array}{l}\text { Death after birth with severe intestinal } \\
\text { defects }\end{array}$ & Ding et al. (2012) \\
\hline CLDN8 & Knockdown & Osteosarcoma cells & Decreased cell viability and proliferation & Xu et al. (2015) \\
\hline CLDN10 & Knockdown & Hepatocellular carcinoma cells & Abolishment invasion & Ip et al. (2007) \\
\hline CLDN11 & Knockout & Mouse & $\begin{array}{l}\text { Deafness, contribution to gastric } \\
\text { carcinogenesis }\end{array}$ & $\begin{array}{l}\text { Gow et al. (2004), } \\
\quad \text { Agarwal et al. (2009) }\end{array}$ \\
\hline CLDN14 & Knockout & Mouse & Deafness & Ben-Yosef et al. (2003) \\
\hline CLDN15 & Knockout & Mouse & $\begin{array}{l}\text { Enlargement upper small intestinal } \\
\text { phenotype }\end{array}$ & Tamura et al. (2008) \\
\hline CLDN16 & Knockdown & Mouse & Delay in weight gain, acidic urine & Himmerkus et al. (2008) \\
\hline CLDN18 & Knockout & Mouse & $\begin{array}{l}\text { Postnatal lung injury and } \\
\text { bronchopulmonary dysplasia }\end{array}$ & LaFemina et al. (2014) \\
\hline CGN & Knockout & Mouse & Viable and fertile; normal TJ function & Guillemot et al. (2012) \\
\hline CGN & Knockdown & Human endothelial cells & Increased thrombin-induced permeability & Tian et al. (2016) \\
\hline OCLN & Knockout & Mouse & $\begin{array}{l}\text { Postnatal growth retardation; normal TJ } \\
\text { function }\end{array}$ & Saitou et al. (2000) \\
\hline OCLN & Knockdown & Canine kidney cells & $\begin{array}{l}\text { Increased TJ permeability to mono- and } \\
\text { divalent inorganic cations }\end{array}$ & Yu et al. (2005) \\
\hline TJP1 & Knockout & Mouse & Embryonic lethal & Katsuno et al. (2008) \\
\hline TJP1 & Knockdown & Mouse epithelial cell clones & TJ formation markedly retarded & Umeda et al. (2004) \\
\hline TJP2 & Knockout & Mouse & Embryonic lethal & Xu et al. (2008) \\
\hline TJP3 & Knockout & Mouse & Viable and fertile & Xu et al. (2008) \\
\hline
\end{tabular}

${ }^{a} C G N$, cingulin; CLDN, claudin; OCLN, occludin; TJP, tight junction protein.

also known as tight junction protein (TJP)-1, -2 and -3) are identified as ubiquitous peripheral membrane TJ proteins (Stevenson et al. 1986, Wittchen et al. 1999). The amino acid sequence of ZO-1/TJP1 is fairly well conserved among vertebrates, with human and bovine ZO-1/TJP1 having 80\% homology and range between 195 and $240 \mathrm{kDa}$ molecular weight. The $\mathrm{N}$-terminus of ZO-1/TJP1 directly interacts with transmembrane TJ proteins (e.g., GUK domain with C-terminal of OCLN) and cytoplasmic proteins recruited to TJ; the PDZ domains mediate the dimerization of the three TJPs/ZOs, which is important in strand assembly; and the C-terminal tail of ZO-1/TJP1 binds to F-actin and CGN (Fanning et al. 2007). The molecular structure makes ZO-1/TJP1 a scaffold protein that connects the TJ membrane proteins (e.g., OCLN) with cytoskeletons to regulate dynamic TJ assembly (Furuse et al. 1994). Deletion of ZO-1/TJP1 from mouse mammary epithelial cells markedly slowed TJ assembly (Umeda et al. 2004). When ZO-1 and its homolog ZO-2 were both depleted, TJ were unable to assemble in mouse mammary epithelial cells (Umeda et al. 2006). ZO-1 or ZO-2 disruption in mice (Table 1) caused embryonic lethality due to disrupted paracellular barrier and cell junctions
(Katsuno et al. 2008, Xu et al. 2008). The permeability of established TJ for large solutes increased in ZO-1/ TJP1 knockdown canine MDCK cells with altered cell morphology and reorganized apical actin and myosin (Van Itallie et al. 2009). In nonepithelial cells, by direct interaction with $\alpha$-catenin and actin filaments at the $\mathrm{N}$-terminal and C-terminal regions respectively, ZO-1/ TJP1 crosslinks cadherin/catenin complex and actin cytoskeleton, and this is involved in the cadherin-based cell adhesion (Itoh et al. 1997, Van Itallie \& Anderson 2014). Relocalization of ZO-1/TJP1 from the junctional complex to cytosol/nucleus causes the upregulation of genes such as vimentin or matrix metalloproteinase-14, which are part of the epithelial-mesenchymal transition and contribute to tumor invasion (Polette et al. 2007). Collectively, these studies show that TJP/ZO proteins stabilize the TJ complex at the cell membrane by passively linking junctional membrane proteins to the cytoskeleton. Moreover, TJPs/ZOs also directly affect assembly of the cytoskeleton, thus regulating TJ function, cell adhesion and morphological change (Fanning \& Anderson 2009). Whether ZO-1/TJP1 is involved in ovarian function and cancer will be reviewed in a later section. 


\section{Cingulin (CGN)}

Like OCLN, CGN with a molecular weight range of $140-160 \mathrm{kDa}$ is highly conserved across vertebrates (e.g., bovine and human are $87 \%$ homologous in amino acids sequence) and organized as a homodimer with each subunit containing a globular head and tail, and a central alpha-helical rod domain (Cordenonsi et al. 1999). Being first identified in avian brush-border cells (Citi et al. 1988), CGN is localized in the endofacial surfaces of TJ (Citi et al. 1989) and within the cytoplasm (Stevenson et al. 1989). Most of the CGN interactions with other proteins are through its $\mathrm{N}$-terminal globular head and are involved in regulating TJ assembly, cell growth and gene expression (Citi et al. 1988, 1989, Balda \& Matter 2009). The $\mathrm{N}$-terminus head domain of CGN interacts with ZO-1, ZO-2, ZO-3, myosin microtubules and actin filaments-6 (AF-6) (D'Atria \& Citia 2001, Yano et al. 2013); the $\mathrm{COOH}$-terminal interacts with myosin and ZO-3 (Cordenonsi et al. 1999); and the rod domain is involved in dimerization and interaction with a guanine nucleotide exchange factor, GEF-H1 (activator of the small GTPase, Rho member A) (Aijaz et al. 2005). The interaction between CGN and actin in vitro suggests a role of CGN in linking TJ components with actomyosin cytoskeleton, which as mentioned earlier, is important for the assembly of TJ and modulation of paracellular permeability (D'Atria \& Citia 2001, D'Atri et al. 2002). CGN strengthens barrier function of endothelial cells, especially toward small-molecular-weight substances (Schossleitner et al. 2016). In addition, si-RNA-induced knockdown in human pulmonary artery endothelial cells increased thrombin-induced permeability (Tian et al. 2016). In mice, disruption of the CGN gene expression in embryoid body did not block TJ formation but altered the gene expression of other TJ proteins, such as increased OCLN, CLDN2 and CLDN7 (Guillemot et al. 2004). CGN-knockout mice (Table 1) have normal TJ structure and barrier function at the organism level, but have increased CLDN2 protein level in the duodenum and a depressed response to duodenal mucosa injury (Guillemot et al. 2012). Deletion of CGN in MDCK cells resulted in increased CLDN2 and ZO-3 mRNA and protein levels, increased activation of G1/S phase transition and increased cell density (Guillemot \& Citi 2006). However, overexpression of CGN did not show the expected negative effects in MDCK cells due to some unknown compensatory mechanism (Paschoud \& Citi 2008). Perhaps paracingulin, another adaptor protein that shows structural homology and dynamic behavior similar to CGN (Paschoud et al. 2011) was downregulated to compensate for overexpression of CGN, but further work will be needed to verify this suggestion. CGN has been detected at TJ, while paracingulin has been detected in both TJ and AJs, but the two distinctly interact with actin and microtubule cytoskeletons (Paschoud et al. 2011). A knockdown study in MDCK cells showed that deletion of both proteins resulted in unexpected downregulation of TJ proteins (CLDN2, CLDN3, ZO-3) without causing changes in junctional structure although junction assembly was delayed (Guillemot et al. 2013, 2014). CGN is also regulating neural crest cell migration where both knockdown and overexpression caused increased cell migration (Wu et al. 2011) an important trait in cancer cells. Thus, CGN is important in regulating TJ function and intracellular activity, such as cell proliferation, differentiation and migration. The role of CGN in ovarian function and cancer will be reviewed below.

\section{Claudins}

Claudins (CLDN) are tetraspan integral membrane proteins that belong to the peripheral myelin protein 22 (PMP22)/CLDN superfamily, and firstly named by Furuse et al. (1998). They are important components of tight junctions in regulating paracellular permeability and maintaining cell polarity in endothelial and epithelial cells (Furuse et al. 1998, Lal-Nag \& Morin 2009). In mice, rats and other mammals, a total of 24 CLDN genes (CLDN124) were found, whereas humans and chimpanzees had 23 known CLDN genes (absent CLDN23). The 24 mammalian members of CLDN protein family are $20-24 \mathrm{kDa}$ in size, most of them are $22-24 \mathrm{kDa}$, which span the cellular membrane 4 times with the $\mathrm{N}$-terminus and C-terminus both located in the cytoplasm. The two extracellular loops are highly conserved with 60 and 24 residues, respectively. The only intracellular loop is about 20 residues (Lal-Nag \& Morin 2009). The amino acid sequences of the second and third transmembrane regions are more diverse, while the sequences of the first and fourth are highly conserved. Several charged amino acids in the 60-residue extracellular loop could have an effect on paracellular ion selectivity (Lal-Nag \& Morin 2009). The carboxyterminal tail among CLDN proteins show the most sequence and size heterogeneity, which contains a PDZ-domain-binding motif (Hamazaki et al. 2002, Roh et al. 2002, Rüffer \& Gerke 2004, Van Itallie \& Anderson 2006), targeting various posttranslational modifications (Van Itallie et al. 2005, GonzálezMariscal et al. 2008) to determine the structure and function of CLDN proteins. Like other TJ proteins, the CLDN proteins show a high range of sequence similarity (e.g., 88-94\% amino acid homology between CLDN1-5 of human and bovine).

Overexpression of CLDN2 in rat umbrella cells using in situ adenoviral transduction increased the permeability of the paracellular route toward ions rather than large organic molecules in vitro and initiated an inflammatory process (Montalbetti et al. 2015). Human prostate cancer cells overexpress CLDN3 and CLDN4 to make these cells particularly sensitive to cytolysis by clostridium perfringens enterotoxin (CPE) resulting from the claudins aberrant distribution 
over the plasma membrane (Romanov et al. 2014). Overexpression of CLDN1-induced expression of matrix metalloproteinase-2 (MMP-2) and cell invasion and migration in normal liver and non-invasive human hepatocellular carcinoma (HCC) cells (Yoon et al. 2010). On the contrary, RNA interference of CLDN1 completely suppressed cell invasion in invasive HCC cells (Yoon et al. 2010). Knockout or knockdown models of CLDN genes and their phenotypes are listed as Table 1. Collectively, expression disorder of claudins could bring dysfunction of endothelial and epithelial cells and consequently lead to functional deficiency, tumors and/or cancers. Evidence for the role of CLDNs in normal ovarian function and cancer will be reviewed in a later section.

\section{Regulation of $\mathrm{TJ}$ proteins}

Expression of TJ proteins (e.g., OCLN, ZO-1) and their mRNAs were shown to be regulated by various growth and differentiation factors (e.g. TGF $\beta$, GDF9, IGF1, estradiol) in different mammalian tissues, such as mouse retina (Walshe et al. 2009), rat colon (Braniste et al. 2009) and rat Sertoli cells (Nicholls et al. 2009). Aberrations in hormonal regulation of TJ proteins is suggested to be involved in some blood/tissue barrier dysfunctions, such as diabetic retinopathy and metastasis in certain invasive human epithelial cancers (Osanai et al. 2006, Martin et al. 2010, Akimoto et al. 2016). A reduction in OCLN protein phosphorylation by vascular endothelial growth factor (VEGF) was shown to contribute to the increased vascular permeability of human retinal endothelial cells (Harhaj et al. 2006). In a diabetic retinopathy study, high glucose levels activated VEGF and IGF1 receptor signaling, which resulted in the disruption of TJ by downregulating OCLN protein content in cultured human retinal endothelial cells (Spoerri et al. 2006). Bovine mammary epithelial cells transfected with IGF1 had reduced OCLN protein content and provided no paracellular transport barrier in a phenol red transport test (Paye et al. 2007). TGF- $\beta$ also increased bovine retinal endothelial cell permeability by reducing OCLN protein content (Behzadian et al. 2001). Using the same model system of bovine retinal endothelial cells, cortisol increased barrier properties with increased OCLN and CLDN5 protein content (Felinski et al. 2008, Keil et al. 2013). Glucocorticoids also increased ZO-1 protein levels in human mammary epithelial cells (Singer et al. 1994) and human corneal endothelial cells (Underwood et al. 1999). Androgens are of great importance in initiating and maintaining the normal function of TJ in the male rats (McCabe et al. 2010, Kolasa et al. 2011). IFN $\gamma$ increased monolayer permeability and decreased ZO-1 protein and mRNA in T84 human intestinal epithelial cells (Youakim \& Ahdieh 1999). TNF $\alpha$ disrupted TJ barrier function, downregulated TJ proteins (i.e., OCLN, ZO-1) in brain vascular endothelial cells of humans (Abdullah et al. 2015), mice (Lv et al. 2010) and cattle (Anda et al. 1997), as well as in rat intestinal cells (Song et al. 2009, Shen et al. 2013), bovine retinal endothelial cells (Aveleira et al. 2010) and corneal endothelial cells (Rajashekhar et al. 2014). Collectively, these studies indicate that TJ are dynamic structures, and gene expression and function of various TJ proteins are under regulation of a variety of hormones, including cytokines, steroids and growth factors.

In addition to the protein expression level, phosphorylation status of TJ proteins by kinase and phosphatase and other cellular and extracellular factors (e.g., EGF, VEGF, cytokines) also regulate some functions of TJ and the recruitment of TJ proteins to the cell-cell contact sites (Feldman et al. 2005, Harhaj et al. 2006) in different tissues, such as human intestinal epithelial cells (Yoshida et al. 2005), bovine retinal endothelial cells (Murakami et al. 2012) and rat mammary epithelial tumor cells (Buse et al. 1995, Woo et al. 1996).

In summary, TJ can serve as functional structures that receive and distribute signals from both inside and outside of cells to control formation of cell-cell contacts and paracellular permeability and to modulate intracellular activities, such as cell growth and migration and gene expression (Balda \& Matter 2009, Spadaro et al. 2012). The TJ proteins (i.e., OCLN, CLDN, TJP1 and CGN) are key regulators that carry out these functions, and these TJ proteins are hormonally regulated. The role of these TJ proteins in ovarian function will be discussed later.

\section{Ovarian follicular antrum formation}

One characteristic of folliculargrowth is the formation and enlargement of an antrum. Follicular fluid (FFL) is derived from the systemic circulation through thecal capillaries, and fluid or molecules transported from microvessels to the antrum need to cross the blood-follicle barrier (BFB), which is a size- and charge-selective structure composed of the vascular endothelium, subendothelial basement membrane, theca interstitium, basement membrane and membrana granulosa (Siu \& Cheng 2012). FFL shares the low-molecular-weight components with serum, but shares fewer of the large-molecular-weight components (>100 kDa) (Rodgers \& Irving-Rodgers 2010), because of the basement membrane acting as a molecular sieve to blood-borne proteins (Shalgi et al. 1973, Ohno et al. 2016). Concentrations of large proteins increase with increasing follicle size in cattle (Andersen et al. 1976) and mice (Zhou et al. 2007). Water transport across the follicular wall exists at both transcellular and paracellular levels and GC express aquaporins to facilitate this transcellular water transport (Huang et al. 2006, Rodgers \& Irving-Rodgers 2010). Different aquaporins exist in GC of different species with aquaporin 1, 5 and 9 in porcine (Skowronski et al. 2009), aquaporin 7, 8 and/or 9 in rats (McConnell et al. 2002), aquaporin 1, 2, 3, 4 and 9 in women (Qu et al. 2010, Thoroddsen et al. 2011) 
and aquaporin 3 and 9 in sheep (Sales et al. 2016). To date, no study has evaluated which aquaporins exist in GC of cattle.

The osmotic potential within the follicular antrum also drives the paracellular water transport, in addition to the transcellular transport of water. The greater osmotic potential inside the antrum is maintained by high-molecular-weight molecules (up to $300 \mathrm{kDa}$ ) produced by GC (e.g., hyaluronan, chondroitin sulfate), and these proteins cross-linking and recruiting other relatively smaller proteins from circulation (i.e., inter- $\alpha$ inhibitor, proteoglycan link protein-1) (Rodgers \& IrvingRodgers 2010). Hyaluronan exists in the FFL of cattle (Clarke et al. 2006) and humans (Saito et al. 2000). Bovine GC in vitro produce hyaluronan (Schoenfelder \& Einspanier 2003) and this protein is localized adjacent to and between GC in human antral follicles (Saito et al. 2000). Hyaluronan associates with proteoglycan-linked proteins (Sun et al. 1999, 2003) and inter- $\alpha$-inhibitor (Rugg et al. 2005), thus retains them in the follicular antrum. Inter- $\alpha$-inhibitor was shown in the FFL of large antral and preovulatory follicles in pigs (Nagyova et al. 2004), mice (Zhou et al. 2007) and cattle (Clarke et al. 2006). These studies indicate BFB contains paracellular junctional structures that control molecule transport, especially large proteins across the follicular wall and limit the escape of these proteins from the follicular antrum. The TJ protein, OCLN was shown responsible for paracellular permeability towards large-sized molecules in the mouse intestine (Al-Sadi et al. 2011). Therefore, it is reasonable to speculate that cellular junctions, especially TJ within ovarian follicular cells will lessen so that FFL accumulation becomes faster during development of late-stage antral follicles. However, further research will be required to verify this suggestion. The role of TJ proteins in ovarian function will be discussed next.

\section{TJ proteins and ovarian function}

Little work has been done to understand the role of TJ proteins in ovarian function. In the male gonad, TJ formed in Sertoli cells are important components of the blood-testis barrier (BTB) and serve as a barrier to separate adluminal germ cells from the circulation, a requirement for normal spermatogenesis (Mruk \& Cheng 2010). Knockout of TJ proteins (i.e., CLDN11, OCLN) showed impaired Sertoli cell TJ permeability and compromised fertility in mice (Saitou et al. 2000, Mazaud-Guittot et al. 2010). Also, expression of TJ proteins (i.e., claudins, OCLN) and the permeability of $\mathrm{T} J$ in rat Sertoli cells are regulated by many different hormones, including androgens (Kolasa et al. 2011), interleukin 6 (Pérez et al. 2012), GDF9 (Nicholls et al. 2009), TGF $\beta$ (Lui et al. 2001), activin and inhibin (Wong et al. 2004). Of all knockout/knockdown studies with altered CLDNs, only one (i.e., CLDN3; Table 1) showed an altered ovarian phenotype (Sun et al. 2011). However, the study of TJ in the female reproductive system, especially during follicular development has not been thoroughly investigated.

The localization and function of TJ in ovarian follicles depend on the species being studied (Fig. 1). In mice, TJ are located in the theca externa and thecal vascular endothelial cells (Toshimori \& Ōura 1982), and AJ but not TJ exist in oocytes and GC (Mora et al. 2012). Protein localization of ZO-1/TJP1 in GC and oocytes of mice is related to $\mathrm{AJ}$ instead of $\mathrm{TJ}$ and may have a role in oocyteGC interaction through cytoskeleton and AJ (Mora et al. 2012). In whole ovarian homogenates of mice, CGN and TJP1 mRNA (but not OCLN mRNA) were detected, and CGN protein was localized around GC and oocytes (Fig. 1A and B; Fleming et al. 1993, Mora et al. 2012). Also in mice, both CGN and TJP1 mRNA abundance in isolated (pooled) follicles was less in antral vs primary follicles (Mora et al. 2012) (Table 2). A recent study in cattle reported that GC contain greater CGN mRNA abundance than do TC (Zhang et al. 2017). Another study in mice showed high CGN protein content in fertilized
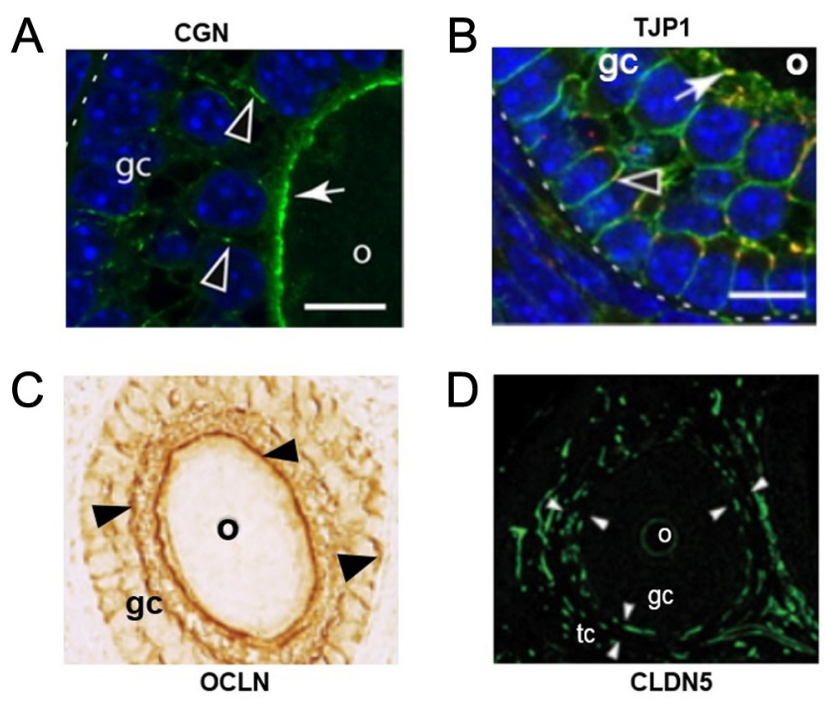

Figure 1 Examples showing localization of cingulin (CGN), tight junction protein 1 (TJP1), occluding (OCLN), claudins (CLDN) in ovarian follicles of mammals. Panel A: CGN immunofluorescence staining in mouse secondary follicles (reprinted from Mora et al. 2012 with permission). Black arrows indicate CGN between granulosa cells. White arrows indicate CGN between oocyte and granulosa cells. Panel B: TJP1 immunofluorescence staining in mouse secondary follicles (reprinted from Mora et al. 2012 with permission). Black arrows indicate TJP1 between granulosa cells. White arrow indicate TJP1 between oocyte and granulosa cells Panel C: OCLN immunostaining in marmoset secondary follicle (reprinted from Rodewald et al. 2007, with permission). Black arrows indicate OCLN between granulosa cells and between oocyte and granulosa cells. Panel D: CLDN5 immunofluorescence staining in marmoset tertiary follicles (reprinted from Rodewald et al. 2007, with permission). White arrows indicate specific staining of CLDN5 between theca cells. gc, granulosa cells; o, oocyte; tc, theca cells. 
Table 2 Chronological summary of the changes in tight junction proteins during ovarian follicular growth.

\begin{tabular}{|c|c|c|c|c|}
\hline References & Species and cell type ${ }^{a}$ & Protein or mRNA ${ }^{b}$ & Directional change & Follicular stages evaluated $^{c}$ \\
\hline Schuster et al. (2004) & Avian GC & OCLN & Decrease & Small to large \\
\hline \multirow[t]{2}{*}{ Rodewald et al. (2007) } & Marmoset GC & OCLN & Decrease & Secondary to antral \\
\hline & Marmoset TC & CLDN5 & Increase & Secondary to antral \\
\hline Clelland and Kelly (2010) & Zebrafish WF & OCLN & No change & Small to large vitellogenic \\
\hline \multirow[t]{2}{*}{ Mora et al. (2012) } & Mice WF & CGN & Decrease & Primary to antral \\
\hline & & TJP1 & Decrease & Primary to antral \\
\hline Hatzirodos et al. (2014) & Bovine TC & CLDN11 & Increase & Small to large antral \\
\hline \multirow[t]{6}{*}{ Zhang et al. (2017) } & Bovine GC & OCLN & Decrease & Small to large antral \\
\hline & Bovine GC & TJP1 & Increase & Small to large antral \\
\hline & Bovine GC & CGN & No change & Small to large antral \\
\hline & Bovine TC & OCLN & Decrease & Small to large antral \\
\hline & Bovine TC & TJP1 & Decrease & Small to large antral \\
\hline & Bovine TC & CGN & No change & Small to large antral \\
\hline
\end{tabular}

${ }^{\mathrm{a}} \mathrm{GC}$, granulosa cells; TC, theca cells; WF, whole follicle; ${ }^{\mathrm{b}} \mathrm{CGN}$, cingulin; CLDN, claudin; OCLN, occludin; TJP1, tight junction protein 1 ; cprimary, preantral follicles with a single layer of granulosa cells; secondary, preantral follicles with multiple layers of granulosa cells.

oocytes, which decreased during early cleavage stage until the embryo started to form TJ, indicating a role of CGN in oogenesis and embryogenesis (Javed et al. 1993). However, CGN's role in folliculogenesis remains to be clarified.

In contrast to CGN, OCLN protein is located on the plasma membrane of GC in primate ovaries and its content decreased during follicular development in primates (Fig. 1C; Rodewald et al. 2007) and chickens (Schuster et al. 2004) (Table 2). Also in humans, OCLN protein is localized to the GC and endothelial cells but not TC and was downregulated by hCG administration in vivo (Groten et al. 2006). In zebrafish mid-vitellogenic follicles, GDF9 decreased OCLN mRNA whereas activin A, BMP15 nor TGF $\beta$ had no effect (Clelland \& Kelly 2011). Gene expression for the TJ proteins OCLN and TJP1 are more prevalent in bovine TC than GC, and both are decreased with follicular development, indicating a role of theseTJ proteins in bovine ovarian folliculogenesis (Zhang et al. 2017) (Table 2). In contrast, in zebrafish ovaries, OCLN protein was found in both GC and TC and its content did not change during follicular development but was regulated by GDF9 in different follicular stages (Clelland \& Kelly 2010) (Table 2). A recent study in cattle revealed that TC gene expression of TJ proteins OCLN, TJP1 and CGN are regulated by autocrine, paracrine and endocrine regulators, such as fibroblast growth factor 9 (FGF9), epidermal growth factor (EGF), dihydrotestosterone (DHT), tumor necrosis factor $\alpha$ (TNF $\alpha$ ), VEGFA and glucocorticoids in vitro (Zhang et al. 2017). Specifically, FGF9 significantly decreased OCLN and CGN mRNA abundance, whereas TNF $\alpha$ and VEGFA increased OCLN mRNA abundance but decreased CGN mRNA abundance (Zhang et al. 2017). CLDN5 protein localizes around granulosa cells in marmoset preantral follicles (Fig. 1D), and in vivo inhibition of VEGFA using soluble recombinant VEGF receptor proteins caused a decrease in theca CLDN5 protein and an increase in granulosa OCLN protein in marmoset antral follicles (Rodewald et al. 2007). Moreover, dexamethasone increased TJP1 and CGN mRNA abundance while EGF decreased and DHT increased abundance of OCLN, TJP1 and CGN mRNA in bovine theca cells (Zhang et al. 2017). Previously, we reported that TC had greater OCLN and TJP1 mRNA than GC, whereas GC had greater CGN mRNA than TC of bovine follicles (Fig. 2A; Zhang et al. 2017). Therefore, we conducted an additional study to determine if abundance of CGN mRNA in GC differed among estrogen-active and estrogen-inactive small, medium and/or large follicles in cattle and found that there were no significant differences in GC CGN mRNA expression among estrogen-inactive follicles of different sizes (Fig. 2B). However, estrogen-active follicles had 3.5 -fold and 2.2 -fold greater $(P<0.05)$ CGN mRNA abundance than estrogen-inactive follicles in medium and large follicles, respectively (Fig. 2B). Furthermore, estradiol concentrations in FFL and CGN mRNA abundance in GC were positively correlated $(r=0.56$, $P<0.01, n=31)$ suggesting that estradiol may regulate GC CGN mRNA expression in cattle (Fig. 3), but further study will be required to verify this. We propose a model whereby normal increases in androgens observed during follicle development increases CGN mRNA in GC, and that with increased androgens, both TJP1 and OCLN gene expression in theca cells increase (Fig. 3A). As follicles grow and develop, more androgens are converted to estrogens thereby reducing the positive effect of androgens on TJP1 and OCLN production (Fig. 3B). We further speculate that increased glucocorticoids and cytokines such as TNF $\alpha$ associated with stress and/or infection will prevent the normal decrease observed during development of normal large follicles, thereby increasing TJP1 and OCLN and causing fluid volume to increase leading to the development of cystic follicles. Zhang et al. (2017) proposed that the downregulation of OCLN and other TJ proteins during follicular development could reduce barrier function thereby participating in increasing follicle size by allowing for an increase in the volume of FFL as well as by allowing additional serum factors into the FFL that 

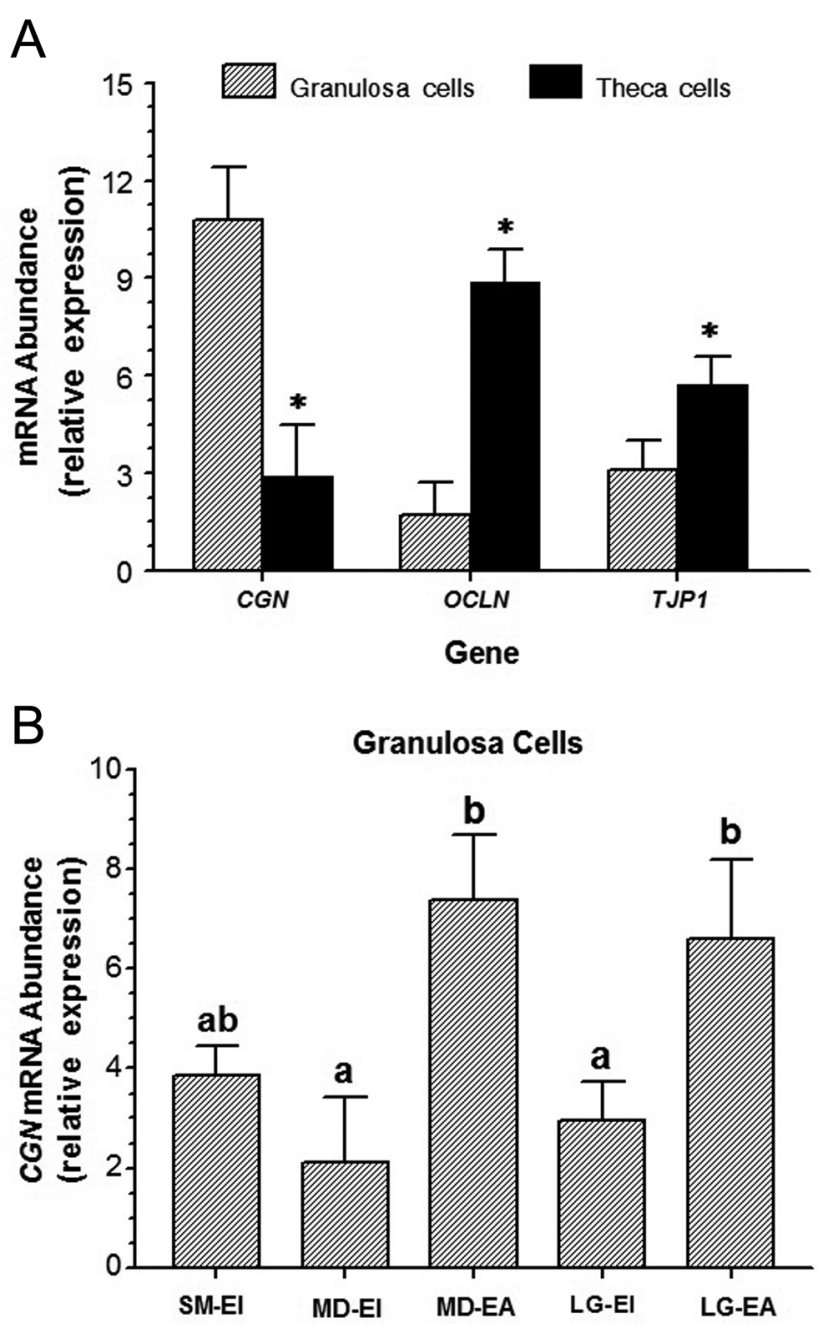

Figure 2 Expression of $O C L N, T J P 1$ and $C G N$ in granulosa and theca cells of bovine antral follicles. Panel A: Abundance of OCLN, TJP1 and CGN mRNA in granulosa and theca cells of small and large antral follicles. Data are modified (averaged across small and large follicles) from Zhang et al. (2017) with permission. Within target gene, asterisk $(*)$ indicates theca cell mean differs $(P<0.05)$ from granulosa cell mean. Panel B: CGN mRNA in small (SM)-, medium (MD)- and large (LG)-estrogen-inactive (EI) and estrogen-active (EA) follicles. Granulosa cells (GC) were collected from MD and LG antral follicles individually, whereas GC from several SM antral follicles were pooled. Ovaries from a total of 8 cattle were used. Cells were lysed and extracted for RNA, and FFL was collected for RIA to ascertain estrogen status of follicles (Schütz et al. 2016). Values ( $n=5-8$ /group) are normalized to constitutively expressed $18 \mathrm{~S}$ ribosomal RNA. ${ }^{a, b}$ Means ( \pm S.E.M.) without a common letter differ $(P<0.05)$.

potentially may directly impact GC functions. A model for how these various hormones and growth factors regulate TJ proteins during follicular development in cattle is summarized in Fig. 3.

Of the transmembrane TJ proteins, claudins have been the most studied in the ovary, and evidence is now accumulating to support an important role for claudins in regulating ovarian follicle development.
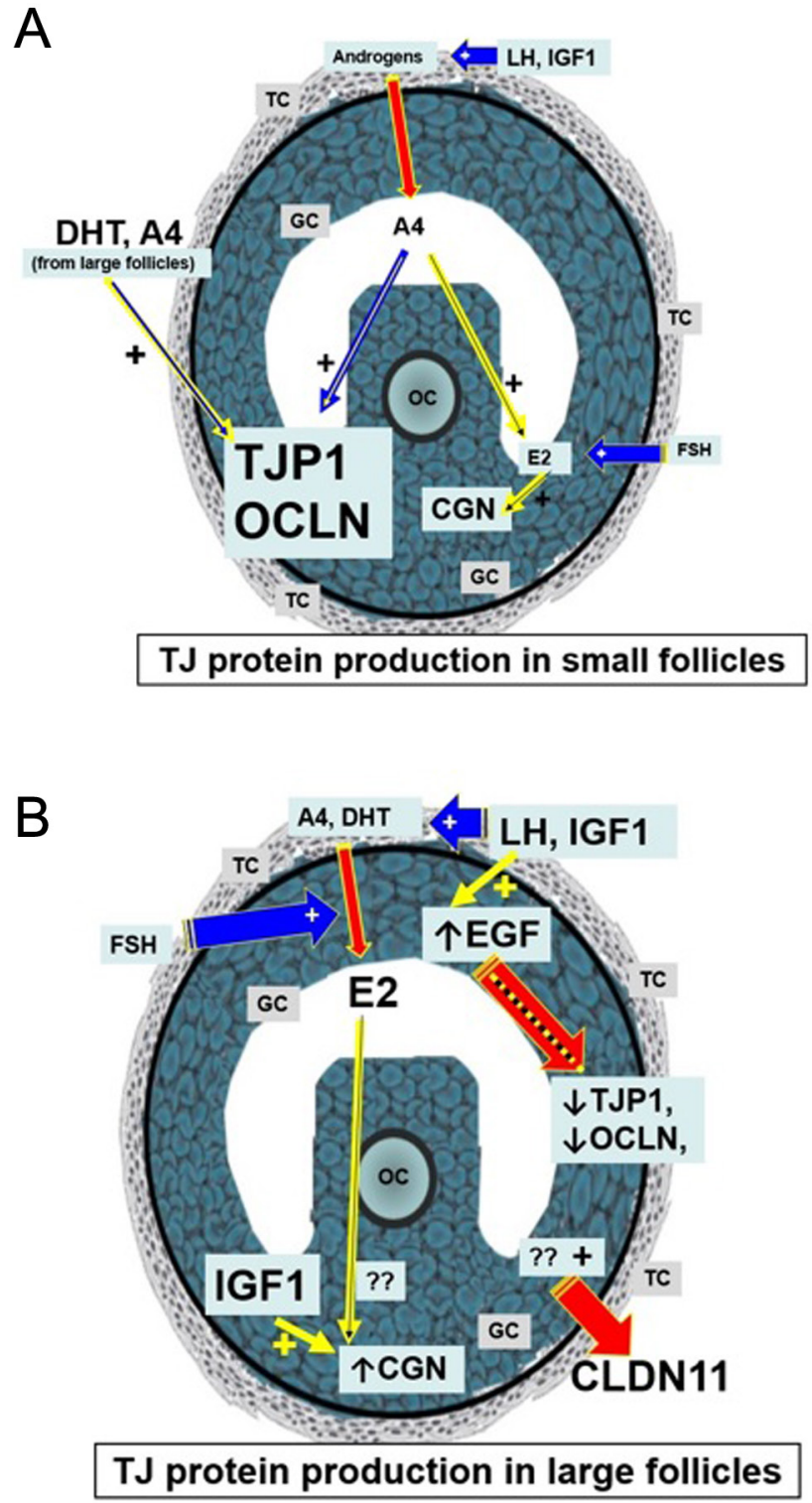

Figure 3 Schematic model summarizing the interaction among tight junction proteins, hormones and growth factors during small follicle development (Panel A) and during large follicle development (Panel B) in cattle. Tight junction protein 1 (TJP1), occluding (OCLN), claudins (CLDN) and cingulin (CGN) dashed line indicates inhibitory effects; solid line with a + , indicates stimulatory effects. As follicles develop (panel A), androgens are stimulatory (solid line) to small follicle TJP1 and OCLN production/expression. These small antral follicles have low amounts of free IGF1 and high amounts of FGF9 mRNA stimulating increased amounts of TJP1, OCLN and CLDN. As follicles enlarge (panel B), androgens are converted to estrogens (which have no effect on TJP1, OCLN and CGN) while luteinizing hormone (LH) induces epidermal growth factor (EGF)-like peptide synthesis which subsequently inhibits TJP1 and OCLN production. These large antral follicles have increased amounts of free IGF1 and reduced amounts of FGF9 mRNA, which also contributes to decreased amounts of TJP1 and OCLN . Factors increasing theca CLDN11 and granulosa CGN production are unknown but may include estradiol (E2). The basement membrane is the thick line separating theca cells (TC) from granulosa cells (GC). 
CLDN1, 2, 4, 7 and 8 mRNAs were broadly expressed in the ovary of zebrafish (Clelland \& Kelly 2010), and CLDN1 and 7 proteins were immunohistochemically localized in human ovarian GC tumors (Soini \& Talvensaari-Mattila 2006). CLDN1 was exclusively localized to the plasma membrane of steroidogenic cells and ovarian surface epithelium in the human corpus luteum (Zhu et al. 2004, Groten et al. 2006, Herr et al. 2015). CLDN5 protein and/or CLDN5 mRNA was exclusively localized to the theca vasculature and endothelial compartment in human corpus luteum (Groten et al. 2006, Rodewald et al. 2007, Herr et al. 2015), as well as the endothelial cells within the ovaries (Kitajima et al. 2006). In equine tissues, as determined by the Western blotting, CLDN1, 2, 4 and 5 were identified in uterus, and CLDN5 was strongly expressed in ovary (Lee et al. 2016). Thus, species differences may exist in terms of which CLDN is important for follicular development.

CLDN proteins in endothelial and epithelial cells of ovaries have been reported to be regulated by hormones and altered during ovarian dysfunction. In marmoset monkeys, CLDN5 protein content of theca increases during follicular growth, from the late secondary to the antral and ovulatory stage, and VEGF inhibition decreases CLDN5 protein content of TC (Rodewald et al. 2007) (Table 2). In human GC, hCG administration significantly up-regulated CLDN11 mRNA by 18.6fold (Wissing et al. 2014), and after treatment with LH and FSH, CLDN3 mRNA was markedly elevated (Rimon et al. 2004). Without FSH-R signaling, CLDN3, 4 , and 11 mRNA were selectively upregulated, whereas CLDN1 mRNA decreased in ovarian surface epithelium and tumors in mice (Aravindakshan et al. 2006) suggesting species differences exist in terms of the hormonal regulation of the specific CLDN. Exogenous GDF9 reduced the transcript abundance of CLDN7 in mid-vitellogenic follicles of zebrafish whereas activin A, BMP15, and TGF $\beta$ had no effect on CLDN7 mRNA (Clelland \& Kelly 2011). Also in zebrafish, CLDN8, 10 and 12 demonstrated stage specific sensitivity to estradiol, whilst in mid-vitellogenic follicles CLDN4 and $7 \mathrm{mRNA}$ abundance increased in response to hCG treatment (Clelland \& Kelly 2011). For human ovarian hyperstimulation syndrome (OHSS), endothelial CLDN5 protein content was decreased by hCG alone (Rodewald et al. 2009). In rats, PMSG and hCG administration decreased both CLDN5 protein and CLDN5 mRNA (Kitajima et al. 2006), but CLDN5 protein content was increased by treatment with a VEGF inhibitor (Scotti et al. 2014a). Also, CLDN5 protein content was up-regulated in non-ovarian human endothelial cells incubated for $24 \mathrm{~h}$ in the presence of FFL from polycystic ovary syndrome (PCOS) patients vs FFL from control patients (Scotti et al. 2014b). Recently, Hatzirodos et al. (2014) reported that CLDN11 mRNA abundance in TC is greater in large vs small antral follicles of cattle (Table 2), which is opposite to what was observed for another transmembrane TJ protein, OCLN (Zhang et al. 2017) and suggests several TJ proteins may be involved in follicular development in cattle. In mice, CLDN11 (95\% homologous to bovine CLDN11) was one of the top estrogen-upregulated genes in whole ovarian extracts (Liew et al. 2011). Clearly, further research is needed to elucidate the hormonal control and role of these various CLDNs in ovarian follicular development.

TJ were also shown to be involved in the function of corpus luteum $(\mathrm{CL})$ in women (Brassart \& Maillet 1975, Brassart et al. 1976) and baboons (Khan-Dawood et al. 1996). Specifically, TJP1 immunoreactivity was greatest in the mid-luteal phase than the early and late phases of the baboon (Khan-Dawood et al. 1996). VEGF is thought to be the main FFL factor that caused increased vascular permeability in human ovarian hyperstimulation syndrome because using an in vitro model for cell permeability, human FFL as well as VEGF treatment decreased ZO-1/TJP1 expression and stimulated cell permeability in cultured bovine aortic endothelial cells (Levin et al. 1998). VEGFA is also considered essential to luteal structure and function (Woad \& Robinson 2016). VEGF and hCG decreased expression of TJ proteins (i.e., OCLN) during follicular development and CL formation in primates (Rodewald et al. 2007, Herr et al. 2015), and it was suggested that VEGF altered luteal permeability via regulation of CLDN5 (Rodewald et al. 2007). Recently, VEGFA was shown to increase OCLN mRNA and decrease CGN mRNA in theca cells of cattle (Zhang et al. 2017). Therefore, hormones that regulate vascular development may also be regulating TJ proteins.

Ovarian cancer is the leading cause of gynecologic malignancy death (the fifth leading cause of cancer death for women in the United States) with only a 15-30\% survival rate for women (Györffy et al. 2008, Liu et al. 2015). Unfortunately, multiple cell types within the ovary are known to transform into ovarian cancer (Murphy 2010) including epithelial cells (van Baal et al. 2017) and germ cells (Nogales et al. 2014). In three studies, differential ovarian tumor ZO-1/TJP1 gene expression was associated with human ovarian cancer therapy response (Györffy et al. 2008). Although ZO-1 (i.e., TJP1) is submembrane protein of TJ, it has a role as a candidate tumor suppressor because of the $\mathrm{SH} 3$ domain (Hough et al. 1997) and is important for regulating cell proliferation and differentiation (Pozzi \& Zent 2010, Spadaro et al. 2012). ZO-1/TJP1 is downregulated in proliferative cells, different cancer and tumor cells, and several models of epithelial mesenchymal transition (Balda \& Matter 2009).

Overexpression of CLDN3 (Hough et al. 2000, Rangel et al. 2003a, Santin et al. 2005, He et al. 2013), CLDN4 (Rangel et al. 2003a, Santin et al. 2005, Honda et al. 2006, Zhu \& Sundfeldt 2007), CLDN7 (Györffy et al. 2008, Dahiya et al. 2011) and CLDN16 
Table 3 Chronological summary of evidence for a role of tight junction proteins in development of ovarian cancer.

\begin{tabular}{|c|c|c|c|c|}
\hline References & Species & Protein or mRNA ${ }^{a}$ & Over or under expression & Specific cell, tumor or tissue type ${ }^{b}$ \\
\hline Hough et al. (2000) & Human & CLDN3 and 4 & Overexpressed & Several OVT types \\
\hline Rangel et al. (2003a) & Human & CLDN3 and 4 & Overexpressed & Several OVT types \\
\hline Rangel et al. (2003b) & Human & CLDN16 & Overexpressed & Several OVT types \\
\hline Santin et al. (2005) & Human & CLDN3 and 4 & Overexpressed & $\begin{array}{l}\text { Chemotherapy-resistant/recurrent OVT vs } \\
\text { chemotherapy-naïve OVT }\end{array}$ \\
\hline Zhu and Sundfeldt (2007) & Human & CLDN3 and 4 & Overexpressed & Several OVT types \\
\hline \multirow{2}{*}{ Györffy et al. (2008) } & Human & TJP1 & Overexpressed & Several OVT types \\
\hline & & CLDN7 & Overexpressed & Several OVT types \\
\hline Dahiya et al. (2011) & Human & CLDN7 & Overexpressed & Several OVT types \\
\hline Sun et al. (2011) & Human/mouse & CLDN3 & Underexpressed & $\downarrow$ SKOV3 tumor size in mice \\
\hline He et al. (2013) & Human/mouse & CLDN3 & Underexpressed & $\downarrow$ SKOV3 tumor size in mice \\
\hline
\end{tabular}

${ }^{a} \mathrm{CLDN}$, claudin; ${ }^{b} \mathrm{OVT}$, ovarian tumor cell; SKOV3, human ovarian epithelial cell line; $\downarrow$, decrease.

(Rangel et al. 2003b) mRNAs are linked to human ovarian tumorigenesis and malignant transformation (Table 3). In particular, CLDN3 (Rangel et al. 2003a) and CLDN7 (Dahiya et al. 2011) are frequently overexpressed in ovarian cancer tumors, and ovarian cancer growth in experimental models has been diminished by inhibiting CLDN3 (Sun et al. 2011, He et al. 2013). Interestingly, Santin et al. (2005) found that chemotherapy-resistant/ recurrent ovarian tumors had greater expression of CLDN3 and CLDN4 than chemotherapy-naïve ovarian cancers. Using an immortalized human ovarian cell line, OVCAR2, transepithelial resistance was decreased and permeability was increased with knockdown of CLND7 (Dahiya et al. 2011). In human endometrial carcinoma, OCLN protein decreases with progression of cancer (Tobioka et al. 2004). Collectively, these previous studies indicate that TJ proteins may be involved in ovarian and reproductive cancers development in addition to normal follicular and luteal development.

Studies summarized here indicate that expression of TJ proteins in follicular cells change during follicular development and are hormonally regulated. Because TJ control paracellular permeability of cell layers as well as cellular activities, the role of TJ in controlling antrum enlargement of ovarian follicles and function of follicular cells in cattle and other species should be further investigated.

\section{Declaration of interest}

The authors declare that there is no conflict of interest that could be perceived as prejudicing the impartiality of the review.

\section{Funding}

This work was supported in part by: National Natural Science Foundation of China (31501950), Beijing Nova Program (Z141105001814046), the Oklahoma State University Agricultural Experiment Station (OKL02970), The Endowment of Howard $M$ and Adene R. Harrington Chair in Animal Science (Project 21-58500) and State Scholarship Fund of China (201509110025).

\section{References}

Abdullah Z, Rakkar K, Bath PM \& Bayraktutan U 2015 Inhibition of TNF$\alpha$ protects in vitro brain barrier from ischaemic damage. Molecular and Cellular Neuroscience 69 65-79. (https://doi.org/10.1016/j. mcn.2015.11.003)

Agarwal R, Mori Y, Cheng Y, Jin Z, Olaru AV, Hamilton JP, David S, Selaru FM, Yang J, Abraham JM et al. 2009 Silencing of claudin-11 is associated with increased invasiveness of gastric cancer cells. PLOS ONE 4 e8002. (https://doi.org/10.1371/journal.pone.0008002)

Aijaz S, D'Atri F, Citi S, Balda MS \& Matter K 2005 Binding of GEF-H1 to the tight junction-associated adaptor cingulin results in inhibition of rho signaling and G1/S phase transition. Developmental Cell 8 777-786. (https://doi.org/10.1016/j.devcel.2005.03.003)

Akimoto T, Takasawa A, Murata M, Kojima Y, Takasawa K, Nojima M, Aoyama T, Hiratsuka Y, Ono Y, Tanaka S et al. 2016 Analysis of the expression and localization of tight junction transmembrane proteins, claudin-1, -4, -7, occludin and JAM-A, in human cervical adenocarcinoma. Histology and Histopathology 31 921-931. (https:// doi.org/10.14670/HH-11-729)

Al-Sadi R, Khatib K, Guo S, Ye D, Youssef M \& Ma T 2011 Occludin regulates macromolecule flux across the intestinal epithelial tight junction barrier. American Journal of Physiology: Gastrointestinal and Liver Physiology 300 G1054-G1064. (https://doi.org/10.1152/ajpgi.00055.2011)

Anda T, Yamashita H, Khalid H, Tsutsumi K, Fujita H, Tokunaga Y \& Shibata S 1997 Effect of tumor necrosis factor-alpha on the permeability of bovine brain microvessel endothelial cell monolayers. Neurological Research 19 369-376. (https://doi.org/10.1080/01616412.1997.11758 599)

Andersen MM, Kroll J, Byskov AG \& Faber M 1976 Protein composition in the fluid of individual bovine follicles. Journal of Reproduction and Fertility 48 109-118. (https://doi.org/10.1530/jrf.0.0480109)

Aravindakshan J, Chen X \& Sairam MR 2006 Differential expression of claudin family proteins in mouse ovarian serous papillary epithelial adenoma in aging FSH receptor-deficient mutants. Neoplasia 8 984-994. (https://doi.org/10.1593/neo.06529)

Aveleira CA, Lin C-M, Abcouwer SF, Ambrósio AF \& Antonetti DA 2010 TNF- $\alpha$ signals through PKC $\zeta / N F-\kappa B$ to alter the tight junction complex and increase retinal endothelial cell permeability. Diabetes 59 2872-2882. (https://doi.org/10.2337/db09-1606)

Balda MS \& Matter K 2000 The tight junction protein ZO-1 and an interacting transcription factor regulate ErbB-2 expression. $E M B O$ Journal 19 2024-2033. (https://doi.org/10.1093/emboj/19.9.2024)

Balda MS \& Matter K 2009 Tight junctions and the regulation of gene expression. Biochimica et Biophysica Acta 1788 761-767. (https://doi. org/10.1016/j.bbamem.2008.11.024)

Balda MS, Whitney JA, Flores C, González S, Cereijido M \& Matter K 1996 Functional dissociation of paracellular permeability and transepithelial electrical resistance and disruption of the apical-basolateral intramembrane diffusion barrier by expression of a mutant tight junction membrane protein. Journal of Cell Biology 134 1031-1049. (https://doi. org/10.1083/jcb.134.4.1031)

Balda MS, Flores-Maldonado C, Cereijido M \& Matter K 2000 Multiple domains of occludin are involved in the regulation of paracellular 
permeability. Journal of Cellular Biochemistry 78 85-96. (https:// doi.org/10.1002/(SICI)1097-4644(20000701)78:1<85::AIDJCB8>3.0.CO;2-F)

Balda MS, Garrett MD \& Matter K 2003 The ZO-1-associated Y-box factor ZONAB regulates epithelial cell proliferation and cell density. Journal of Cell Biology 160 423-432. (https://doi.org/10.1083/ jcb.200210020)

Bamforth SD, Kniesel U, Wolburg H, Engelhardt B \& Risau W 1999 A dominant mutant of occludin disrupts tight junction structure and function. Journal of Cell Science 112 1879-1888.

Bauer H, Stelzhammer W, Fuchs R, Weiger T, Danninger C, Probst G \& Krizbai I 1999 Astrocytes and neurons express the tight junction-specific protein occludin in vitro. Experimental Cell Research 250 434-438. (https://doi.org/10.1006/excr.1999.4558)

Behzadian MA, Wang X-L, Windsor LJ, Ghaly N \& Caldwell RB 2001 TGF-ß increases retinal endothelial cell permeability by increasing MMP-9: possible role of glial cells in endothelial barrier function. Investigative Ophthalmology and Visual Science 42 853-859.

Ben-Yosef T, Belyantseva IA, Saunders TL, Hughes ED, Kawamoto K, Van Itallie CM, Beyer LA, Halsey K, Gardner DJ, Wilcox ER et al. 2003 Claudin 14 knockout mice, a model for autosomal recessive deafness DFNB29, are deaf due to cochlear hair cell degeneration. Human Molecular Genetics 12 2049-2061. (https://doi.org/10.1093/hmg/ ddg210)

Bordin M, D'Atri F, Guillemot L \& Citi S 2004 Histone deacetylase inhibitors up-regulate the expression of tight junction proteins. Molecular Cancer Research 2 692-701.

Braniste V, Leveque $M$, Buisson-Brenac C, Bueno L, Fioramonti J \& Houdeau E 2009 Oestradiol decreases colonic permeability through oestrogen receptor $\beta$-mediated up-regulation of occludin and junctional adhesion molecule-A in epithelial cells. Journal of Physiology 587 3317-3328. (https://doi.org/10.1113/jphysiol.2009.169300)

Brassart B \& Maillet M 1975 Junction zones of luteal cells in the luteotrophic phase in humans. Bulletin de l'Association des Anatomistes 59 363-376.

Brassart B, Lansac J, Maillet M \& Soutoul J 1976 Ultrastructural and histochemical study of the zones of the junctions of luteal cells in women. Functional significance. Journal de Gynecologie, Obstetrique et Biologie de la Reproduction 5 483-493.

Buccione R, Schroeder AC \& Eppig JJ 1990 Interactions between somatic cells and germ cells throughout mammalian oogenesis. Biology of Reproduction 43 543-547. (https://doi.org/10.1095/biolreprod43.4.543)

Buse P, Woo PL, Alexander DB, Cha HH, Reza A, Sirota ND \& Firestone GL 1995 Transforming growth factor- $\alpha$ abrogates glucocorticoid-stimulated tight junction formation and growth suppression in rat mammary epithelial tumor cells. Journal of Biological Chemistry 270 6505-6514. (https://doi.org/10.1074/jbc.270.12.6505)

Cereijido M, Contreras RG, Shoshani L, Flores-Benitez D \& Larre I 2008 Tight junction and polarity interaction in the transporting epithelial phenotype. Biochimica et Biophysica Acta 1778 770-793. (https://doi. org/10.1016/j.bbamem.2007.09.001)

Chen Y-H, Merzdorf C, Paul DL \& Goodenough DA 1997 COOH terminus of occludin is required for tight junction barrier function in early xenopus embryos. Journal of Cell Biology 138 891-899. (https://doi.org/10.1083/ jcb.138.4.891)

Citi S 1993 The molecular organization of tight junctions. Journal of Cell Biology 121 485-489. (https://doi.org/10.1083/jcb.138.4.891)

Citi S, Sabanay H, Jakes R, Geiger B \& Kendrick-Jones J 1988 Cingulin, a new peripheral component of tight junctions. Nature 333 272. (https:// doi.org/10.1083/jcb.138.4.891)

Citi S, Sabanay H, Kendrick-Jones J \& Geiger B 1989 Cingulin: characterization and localization. Journal of Cell Science 93 107-122. (https://doi.org/10.1083/jcb.138.4.891)

Citi S, Pulimeno P \& Paschoud S 2012 Cingulin, paracingulin, and PLEKHA7: signaling and cytoskeletal adaptors at the apical junctional complex. Annals of the New York Academy of Sciences 1257 125-132. (https://doi.org/10.1083/jcb.138.4.891)

Clarke HG, Hope SA, Byers S \& Rodgers RJ 2006 Formation of ovarian follicular fluid may be due to the osmotic potential of large glycosaminoglycans and proteoglycans. Reproduction 132 119-131. (https://doi.org/10.1083/jcb.138.4.891)

Clelland ES \& Kelly SP 2010 Tight junction proteins in zebrafish ovarian follicles: stage specific mRNA abundance and response to $17 \beta$-estradiol, human chorionic gonadotropin, and maturation inducing hormone.
General and Comparative Endocrinology 168 388-400. (https://doi. org/10.1083/jcb.138.4.891)

Clelland ES \& Kelly SP 2011 Exogenous GDF9 but not Activin A, BMP15 or TGF $\beta$ alters tight junction protein transcript abundance in zebrafish ovarian follicles. General and Comparative Endocrinology 171 211-217. (https://doi.org/10.1083/jcb.138.4.891)

Cordenonsi M, D'Atri F, Hammar E, Parry DA, Kendrick-Jones J, Shore D \& Citi S 1999 Cingulin contains globular and coiled-coil domains and interacts with ZO-1, ZO-2, ZO-3, and myosin. Journal of Cell Biology 147 1569-1581. (https://doi.org/10.1083/jcb.138.4.891)

D'Atria F \& Citia S 2001 Cingulin interacts with F-actin in vitro. FEBS Letters $\mathbf{5 0 7} 21-24$.

D'Atri F, Nadalutti F \& Citi S 2002 Evidence for a functional interaction between cingulin and ZO-1 in cultured cells. Journal of Biological Chemistry 277 27757-27764. (https://doi.org/10.1083/jcb.138.4.891)

Dahiya N, Becker KG, Wood WH III, Zhang Y \& Morin PJ 2011 Claudin-7 is frequently overexpressed in ovarian cancer and promotes invasion. PLOS ONE 6 e22119. (https://doi.org/10.1371/journal.pone.0022119)

Ding L, Lu Z, Foreman O, Tatum R, Lu Q, Renegar R, Cao J \& Chen YH 2012 Inflammation and disruption of the mucosal architecture in claudin-7-deficient mice. Gastroenterology 142 305-315. (https://doi. org/10.1053/j.gastro.2011.10.025)

Eppig J, Chesnel F, Hirao Y, O'Brien M, Pendola F, Watanabe S \& Wigglesworth K 1997 Oocyte control of granulosa cell development: how and why. Human Reproduction 12 127-132.

Evans WH 2015 Cell communication across gap junctions: a historical perspective and current developments. Biochemical Society Transactions 43 450-459. (https://doi.org/10.1042/BST20150056)

Fahiminiya S \& Gerard N 2010 Follicular fluid in mammals. Gynecologie, Obstetrique and Fertilite 38 402-404. (https://doi.org/10.1016/j. gyobfe.2010.04.010)

Fanning AS \& Anderson JM 2009 Zonula occludens-1 and-2 are cytosolic scaffolds that regulate the assembly of cellular junctions. Annals of the New York Academy of Sciences 1165 113-120. (https://doi.org/10.1111/ j.1749-6632.2009.04440.x)

Fanning AS, Ma TY \& Anderson JM 2002 Isolation and functional characterization of the actin binding region in the tight junction protein ZO-1. FASEB Journal 16 1835-1837. (https://doi.org/10.1096/fj.02$0121 \mathrm{fje})$

Fanning AS, Little BP, Rahner C, Utepbergenov D, Walther Z \& Anderson JM 2007 The unique-5 and- 6 motifs of ZO- 1 regulate tight junction strand localization and scaffolding properties DD. Molecular Biology of the Cell 18 721-731. (https://doi.org/10.1091/mbc.E06-08-0764)

Feldman GJ, Mullin JM \& Ryan MP 2005 Occludin: Structure, function and regulation. Advanced Drug Delivery Reviews 57 883-917. (https://doi. org/10.1016/j.addr.2005.01.009)

Felinski EA, Cox AE, Phillips BE \& Antonetti DA 2008 Glucocorticoids induce transactivation of tight junction genes occludin and claudin-5 in retinal endothelial cells via a novel cis-element. Experimental Eye Research 86 867-878. (https://doi.org/10.1016/j.exer.2008.01.002)

Fleming TP, Hay M, Javed Q \& Citi S 1993 Localisation of tight junction protein cingulin is temporally and spatially regulated during early mouse development. Development 117 1135-1144.

Fortune J, Sirois J, Turzillo A \& Lavoir M 1990 Follicle selection in domestic ruminants. Journal of Reproduction and Fertility Supplement 43 187-198.

Funke L, Dakoji S \& Bredt DS 2005 Membrane-associated guanylate kinases regulate adhesion and plasticity at cell junctions. Annual Review of Biochemistry 74 219-245. (https://doi.org/10.1146/annurev. biochem.74.082803.133339)

Furuse $M$, Hirase T, Itoh M, Nagafuchi A, Yonemura S \& Tsukita S 1993 Occludin: a novel integral membrane protein localizing at tight junctions. Journal of Cell Biology 123 1777-1788. (https://doi. org/10.1083/jcb.123.6.1777)

Furuse M, Fujita K, Hiiragi T, Fujimoto K \& Tsukita S 1998 Claudin-1 and2: novel integral membrane proteins localizing at tight junctions with no sequence similarity to occludin. Journal of Cell Biology 141 1539-1550. (https://doi.org/10.1083/jcb.141.7.1539)

Furuse M, Hata M, Furuse K, Yoshida Y, Haratake A, Sugitani Y, Noda T, Kubo A \& Tsukita S 2002 Claudin-based tight junctions are crucial for the mammalian epidermal barrier: a lesson from claudin-1-deficient mice. Journal of Cell Biology 156 1099-1111. (https://doi.org/10.1083/ jcb.200110122) 
Furuse M, Itoh M, Hirase T, Nagafuchi A, Yonemura S \& Tsukita S 1994 Direct association of occludin with ZO-1 and its possible involvement in the localization of occludin at tight junctions. Journal of Cell Biology 127 1617-1626. (https://doi.org/10.1083/jcb.127.6.1617)

González-Mariscal L, Namorado MC, Martin D, Luna J, Alarcon L, Islas S, Valencia L, Muriel P, Ponce L \& Reyes JL 2000 Tight junction proteins ZO-1, ZO-2, and occludin along isolated renal tubules. Kidney International 57 2386-2402.

González-Mariscal L, Tapia R \& Chamorro D 2008 Crosstalk of tight junction components with signaling pathways. Biochimica et Biophysica Acta 1778 729-756

Gow A, Davies C, Southwood CM, Frolenkov G, Chrustowski M, Ng L, Yamauchi D, Marcus DC \& Kachar B 2004 Deafness in Claudin 11-null mice reveals the critical contribution of basal cell tight junctions to stria vascularis function. Journal of Neuroscience 24 7051-7062. (https://doi. org/10.1523/JNEUROSCI.1640-04.2004)

Groten T, Fraser H, Duncan W, Konrad R, Kreienberg R \& Wulff C 2006 Cell junctional proteins in the human corpus luteum: changes during the normal cycle and after HCG treatment. Human Reproduction 21 3096-3102. (https://doi.org/10.1093/humrep/del286)

Guillemot L \& Citi S 2006 Cingulin regulates claudin-2 expression and cell proliferation through the small GTPase RhoA. Molecular Biology of the Cell 17 3569-3577. (https://doi.org/10.1091/mbc.E06-02-0122)

Guillemot L, Hammar E, Kaister C, Ritz J, Caille D, Jond L, Bauer C, Meda P \& Citi S 2004 Disruption of the cingulin gene does not prevent tight junction formation but alters gene expression. Journal of Cell Science 117 5245-5256. (https://doi.org/10.1242/jcs.01399)

Guillemot L, Schneider Y, Brun P, Castagliuolo I, Pizzuti D, Martines D, Jond L, Bongiovanni M \& Citi S 2012 Cingulin is dispensable for epithelial barrier function and tight junction structure, and plays a role in the control of claudin-2 expression and response to duodenal mucosa injury. Journal of Cell Science 125 5005-5014. (https://doi.org/10.1242/jcs.101261)

Guillemot L, Spadaro D \& Citi S 2013 The junctional proteins cingulin and paracingulin modulate the expression of tight junction protein genes through GATA-4. PLOS ONE 8 e55873. (https://doi.org/10.1371/journal. pone.0055873)

Guillemot L, Guerrera D, Spadaro D, Tapia R, Jond L \& Citi S 2014 MgcRacGAP interacts with cingulin and paracingulin to regulate Rac1 activation and development of the tight junction barrier during epithelial junction assembly. Molecular Biology of the Cell 25 1995-2005. (https:// doi.org/10.1091/mbc.E13-11-0680)

Györffy B, Dietel M, Fekete T \& Lage H 2008 A snapshot of microarraygenerated gene expression signatures associated with ovarian carcinoma. International Journal of Gynecologic Cancer 18 1215-1233. (https://doi. org/10.1111/j.1525-1438.2007.01169.x)

Hamazaki Y, Itoh M, Sasaki H, Furuse M \& Tsukita S 2002 Multi-PDZ domain protein 1 (MUPP1) is concentrated at tight junctions through its possible interaction with claudin-1 and junctional adhesion molecule. Journal of Biological Chemistry 277 455-461. (https://doi.org/10.1074/ jbc.M109005200)

Harhaj NS, Felinski EA, Wolpert EB, Sundstrom JM, Gardner TW \& Antonetti DA 2006 VEGF activation of protein kinase C stimulates occludin phosphorylation and contributes to endothelial permeability. Investigative Ophthalmology and Visual Science 47 5106-5115. (https:// doi.org/10.1167/iovs.06-0322)

Hatzfeld M, Keil R \& Magin TM 2017 Desmosomes and intermediate filaments: their consequences for tissue mechanics. Cold Spring Harbor Perspectives in Biology 9 a029157. (https://doi.org/10.1101/cshperspect. a029157)

Hatzirodos N, Hummitzsch K, Irving-Rodgers HF \& Rodgers RJ 2014 Transcriptome profiling of the theca interna in transition from small to large antral ovarian follicles. PLOS ONE 9 e97489. (https://doi. org/10.1371/journal.pone.0097489)

He Z-Y, Wei X-W, Luo M, Luo S-T, Yang Y, Yu Y-Y, Chen Y, Ma C-C, Liang X \& Guo F-C 2013 Folate-linked lipoplexes for short hairpin RNA targeting claudin-3 delivery in ovarian cancer xenografts. Journal of Controlled Release 172 679-689. (https://doi.org/10.1016/j.jconrel.2013.10.015)

Herr D, Bekes I \& Wulff C 2015 Regulation of endothelial permeability in the primate corpora lutea: implications for ovarian hyperstimulation syndrome. Reproduction 149 R71-R79. (https://doi.org/10.1530/REP13-0296)

Hervé J-C, Bourmeyster N, Sarrouilhe D \& Duffy HS 2007 Gap junctional complexes: from partners to functions. Progress in
Biophysics and Molecular Biology 94 29-65. (https://doi.org/10.1016/j. pbiomolbio.2007.03.010)

Himmerkus N, Shan Q, Goerke B, Hou J, Goodenough DA \& Bleich M 2008 Salt and acid-base metabolism in claudin-16 knockdown mice: impact for the pathophysiology of FHHNC patients. American Journal of Physiology: Renal Physiology 295 F1641-F1647. (https://doi. org/10.1152/ajprenal.90388.2008)

Honda H, Pazin MJ, Ji H, Wernyj RP \& Morin PJ 2006 Crucial roles of Sp1 and epigenetic modifications in the regulation of the CLDN4 promoter in ovarian cancer cells. Journal of Biological Chemistry 281 21433-21444. (https://doi.org/10.1074/jbc.M603767200)

Hough CD, Woods DF, Park S \& Bryant PJ 1997 Organizing a functional junctional complex requires specific domains of the Drosophila MAGUK Discs large. Genes and Development 11 3242-3253. (https:// doi.org/10.1101/gad.11.23.3242)

Hough CD, Sherman-Baust CA, Pizer ES, Montz FJ, Im DD, Rosenshein NB, Cho KR, Riggins GJ \& Morin PJ 2000 Large-scale serial analysis of gene expression reveals genes differentially expressed in ovarian cancer. Cancer Research $606281-6287$.

Hsueh AJ, Kawamura K, Cheng Y \& Fauser BC 2015 Intraovarian control of early folliculogenesis. Endocrine Reviews 36 1-24. (https://doi. org/10.1210/er.2014-1020)

Huang HF, He RH, Sun CC, Zhang Y, Meng QX \& Ma YY 2006 Function of aquaporins in female and male reproductive systems. Human Reproduction Update 12 785-795. (https://doi.org/10.1093/humupd/ dml035)

Ikari A, Sato T, Takiguchi A, Atomi K, Yamazaki Y \& Sugatani J 2011 Claudin-2 knockdown decreases matrix metalloproteinase-9 activity and cell migration via suppression of nuclear Sp1 in A549 cells. Life Sciences 88 628-633. (https://doi.org/10.1016/j.Ifs.2011.02.002)

Ip YC, Cheung ST, Lee YT, Ho JC \& Fan ST 2007 Inhibition of hepatocellular carcinoma invasion by suppression of claudin-10 in HLE cells. Molecular Cancer Therapeutics 6 2858-2867. (https://doi.org/10.1158/1535-7163. MCT-07-0453)

Itoh M, Nagafuchi A, Moroi S \& Tsukita S 1997 Involvement of ZO-1 in cadherin-based cell adhesion through its direct binding to catenin and actin filaments. Journal of Cell Biology 138 181-192. (https://doi. org/10.1083/jcb.138.1.181)

Javed Q, Fleming TP, Hay M \& Citi S 1993 Tight junction protein cingulin is expressed by maternal and embryonic genomes during early mouse development. Development 117 1145-1151.

Kage H, Flodby P, Gao D, Kim YH, Marconett CN, DeMaio L, Kim KJ, Crandall ED \& Borok Z 2014 Claudin 4 knockout mice: normal physiological phenotype with increased susceptibility to lung injury. American Journal of Physiology: Lung Cellular and Molecular Physiology 307 L524-L536. (https://doi.org/10.1152/ajplung.00077.2014)

Katsuno T, Umeda K, Matsui T, Hata M, Tamura A, Itoh M, Takeuchi K, Fujimori T, Nabeshima Y-I \& Noda T 2008 Deficiency of zonula occludens-1 causes embryonic lethal phenotype associated with defected yolk sac angiogenesis and apoptosis of embryonic cells. Molecular Biology of the Cell 19 2465-2475. (https://doi.org/10.1091/ mbc.E07-12-1215)

Keil JM, Liu X \& Antonetti DA 2013 Glucocorticoid induction of occludin expression and endothelial barrier requires transcription factor p54 NONOp54 NONO in transcriptional control of occludin. Investigative Ophthalmology and Visual Science $\mathbf{5 4}$ 4007-4015. (https://doi. org/10.1167/iovs.13-11980)

Khan-Dawood F, Yang J \& Dawood M 1996 Localization and expression of zonula occludens-1 tight junction-associated protein in baboon (Papio anubis) corpora lutea. Human Reproduction 11 1262-1267. (https://doi. org/10.1093/oxfordjournals.humrep.a019369)

Kitajima Y, Endo T, Nagasawa K, Manase K, Honnma H, Baba T, Hayashi T, Chiba H, Sawada N \& Saito T 2006 Hyperstimulation and gonadotropinreleasing hormone agonist modulate ovarian vascular permeability by altering expression of the tight junction protein claudin-5. Endocrinology 147 694-699. (https://doi.org/10.1210/en.2005-0700)

Kolasa A, Marchlewicz M, Wenda-Różewicka L \& Wiszniewska B 2011 DHT deficiency perturbs the integrity of the rat seminiferous epithelium by disrupting tight and adherens junctions. Folia Histochemica et Cytobiologica 49 62-61. (https://doi.org/10.5603/FHC.2011.0010)

LaFemina MJ, Sutherland KM, Bentley T, Gonzales LW, Allen L, Chapin CJ, Rokkam D, Sweerus KA, Dobbs LG, Ballard PL et al. 2014 Claudin-18 deficiency results in alveolar barrier dysfunction and impaired 
alveologenesis in mice. American Journal of Respiratory Cell and Molecular Biology 51 550-558. (https://doi.org/10.1165/rcmb.2013-0456OC)

Lal-Nag M \& Morin PJ 2009 The claudins. Genome Biology 10235. (https://doi.org/10.1186/gb-2009-10-8-235)

Lee B, Kang HY, Lee DO, Ahn C \& Jeung E-B 2016 Claudin-1, 2, 4, and 5: comparison of expression levels and distribution in equine tissues. Journal of Veterinary Science 17 445-451. (https://doi.org/10.4142/ jvs.2016.17.4.445)

Levin ER, Rosen GF, Cassidenti DL, Yee B, Meldrum D, Wisot A \& Pedram A 1998 Role of vascular endothelial cell growth factor in ovarian hyperstimulation syndrome. Journal of Clinical Investigation 102 1978-1985. (https://doi.org/10.1172/JCI4814)

Liew SH, Sarraj MA, Drummond AE \& Findlay JK 2011 Estrogen-dependent gene expression in the mouse ovary. PLOS ONE 6 e14672. (https://doi. org/10.1371/journal.pone.0014672)

Liu Y, Metzinger MN, Lewellen KA, Cripps SN, Carey KD, Harper El, Shi Z, Tarwater L, Grisoli A, Lee E et al. 2015 Obesity contributes to ovarian cancer metastatic success through increased lipogenesis, enhanced vascularity, and decreased infiltration of M1 macrophages. Cancer Research 75 50465057. (https://doi.org/10.1158/0008-5472.CAN-15-0706)

Lui W-Y, Lee WM \& Cheng CY 2001 Transforming growth factor- $\beta 3$ perturbs the inter-sertoli tight junction permeability barrier in vitro possibly mediated via its effects on occludin, zonula occludens- 1 , and claudin-11. Endocrinology 142 1865-1877. (https://doi.org/10.1210/ endo.142.5.8116)

Lv S, Song HL, Zhou Y, Li LX, Cui W, Wang W \& Liu P 2010 Tumour necrosis factor- $\alpha$ affects blood-brain barrier permeability and tight junction-associated occludin in acute liver failure. Liver International $\mathbf{3 0}$ 1198-1210. (https://doi.org/10.1111/j.1478-3231.2010.02211.x)

Martin TA, Mansel RE \& Jiang WG 2010 Loss of occludin leads to the progression of human breast cancer. International Journal of Molecular Medicine 26 723-734.

Mazaud-Guittot S, Meugnier E, Pesenti S, Wu X, Vidal H, Gow A \& Le Magueresse-Battistoni B 2010 Claudin 11 deficiency in mice results in loss of the Sertoli cell epithelial phenotype in the testis. Biology of Reproduction 82 202-213. (https://doi.org/10.1095/ biolreprod.109.078907)

McCabe MJ, Tarulli GA, Meachem SJ, Robertson DM, Smooker PM \& Stanton PG 2010 Gonadotropins regulate rat testicular tight junctions in vivo. Endocrinology 151 2911-2922. (https://doi.org/10.1210/en.20091278)

McCarthy KM, Skare IB, Stankewich MC, Furuse M, Tsukita S, Rogers RA, Lynch RD \& Schneeberger EE 1996 Occludin is a functional component of the tight junction. Journal of Cell Science 109 2287-2298.

McConnell NA, Yunus RS, Gross SA, Bost KL, Clemens MG \& Hughes Jr FM 2002 Water permeability of an ovarian antral follicle is predominantly transcellular and mediated by aquaporins. Endocrinology $\mathbf{1 4 3}$ 2905-2912. (https://doi.org/10.1210/endo.143.8.8953)

McNeil E, Capaldo CT \& Macara IG 2006 Zonula occludens-1 function in the assembly of tight junctions in Madin-Darby canine kidney epithelial cells. Molecular Biology of the Cell 17 1922-1932. (https:// doi.org/10.1091/mbc.E05-07-0650)

Medina R, Rahner C, Mitic LL, Anderson JM \& Van Itallie CM 2000 Occludin localization at the tight junction requires the second extracellular loop. Journal of Membrane Biology 178 235-247. (https:// doi.org/10.1007/s002320010031)

Mihm M \& Bleach E 2003 Endocrine regulation of ovarian antral follicle development in cattle. Animal Reproduction Science 3 217-237. (https:// doi.org/10.1016/S0378-4320(03)00092-7)

Montalbetti N, Rued AC, Clayton DR, Ruiz WG, Bastacky SI, Prakasam HS, Eaton AF, Kullmann FA, Apodaca G \& Carattino MD 2015 Increased urothelial paracellular transport promotes cystitis. American Journal of Physiology: Renal Physiology 309 F1070-F1081. (https://doi. org/10.1152/ajprenal.00200.2015)

Mora JM, Fenwick MA, Castle L, Baithun M, Ryder TA, Mobberley M, Carzaniga R, Franks S \& Hardy K 2012 Characterization and significance of adhesion and junction-related proteins in mouse ovarian follicles. Biology of Reproduction 86 1-14. (https://doi.org/10.1095/ biolreprod.111.096156)

Morita K, Sasaki H, Fujimoto K, Furuse M \& Tsukita S 1999 Claudin-11/ OSP-based tight junctions of myelin sheaths in brain and sertoli cells in testis. Journal of Cell Biology 145 579-588. (https://doi.org/10.1083/ jcb.145.3.579)
Mruk DD \& Cheng C 2010 Tight junctions in the testis: new perspectives. Philosophical Transactions of the Royal Society of London B: Biological Sciences 365 1621-1635. (https://doi.org/10.1098/rstb.2010.0010)

Murakami T, Frey T, Lin C \& Antonetti DA 2012 Protein kinase C $\beta$ phosphorylates occludin regulating tight junction trafficking in vascular endothelial growth factor-induced permeability in vivo. Diabetes $\mathbf{6 1}$ 1573-1583. (https://doi.org/10.2337/db11-1367)

Murphy SK 2010 Targeting ovarian cancer-initiating cells. Anticancer Agents in Medicinal Chemistry 10 157-63. (https://doi. org/10.2174/187152010790909272)

Nagyova E, Camaioni A, Prochazka R \& Salustri A 2004 Covalent transfer of heavy chains of inter- $\alpha$-trypsin inhibitor family proteins to hyaluronan in in vivo and in vitro expanded porcine oocyte-cumulus complexes. Biology of Reproduction 71 1838-1843. (https://doi.org/10.1095/ biolreprod.104.029595)

Nicholls PK, Harrison CA, Gilchrist RB, Farnworth PG \& Stanton PG 2009 Growth differentiation factor 9 is a germ cell regulator of Sertoli cell function. Endocrinology 150 2481-2490. (https://doi.org/10.1210/ en.2008-1048)

Nitta T, Hata M, Gotoh S, Seo Y, Sasaki H, Hashimoto N, Furuse M \& Tsukita S 2003 Size-selective loosening of the blood-brain barrier in claudin-5-deficient mice. Journal of Cell Biology 161 653-660. (https:// doi.org/10.1083/jcb.200302070)

Nogales FF, Dulcey I \& Preda O 2014 Germ cell tumors of the ovary: an update. Archives of Pathology and Laboratory Medicine 138 351-362. (https://doi.org/10.5858/arpa.2012-0547-RA)

Ohno N, Zhou H, Terada N \& Ohno S. 2016 Involvement of follicular basement membrane and vascular endothelium in blood-follicle barrier formation of mice. In: In Vivo Cryotechnique in Biomedical Research and Application for Bioimaging of Living Animal Organs, pp 149-153. Eds S Ohno, N Ohno, \& N Terada. Tokyo: Springer.

Orbán E, Szabó E, Lotz G, Kupcsulik P, Páska C, Schaff Z \& Kiss A 2008 Different expression of occludin and ZO-1 in primary and metastatic liver tumors. Pathology and Oncology Research 14 299-306. (https:// doi.org/10.1007/s12253-008-9031-2)

Osanai M, Murata M \& Nishikiori N 2006 Epigenetic silencing of occludin promotes tumorigenic and metastatic properties of cancer cells via modulation of unique sets of apoptosis-associated genes. Cancer Research 66 9125-9133. (https://doi.org/10.1158/0008-5472.CAN-061864)

Owen GR \& Stokes DL 2010 Exploring the nature of desmosomal cadherin associations in 3D. Dermatology and Research Practice 2010930401. (https://doi.org/10.1155/2010/930401)

Paris L \& Bazzoni G 2008 The protein interaction network of the epithelial junctional complex: A system-level analysis. Molecular Biology of the Cell 19 5409-5421. (https://doi.org/10.1091/mbc.E08-05-0477)

Paschoud S \& Citi S 2008 Inducible overexpression of cingulin in stably transfected MDCK cells does not affect tight junction organization and gene expression. Molecular Membrane Biology 25 1-13. (https://doi. org/10.1080/09687680701474009)

Paschoud S, Yu D, Pulimeno P, Jond L, Turner JR \& Citi S 2011 Cingulin and paracingulin show similar dynamic behaviour, but are recruited independently to junctions. Molecular Membrane Biology 28 123-135. (https://doi.org/10.3109/09687688.2010.538937)

Paye JM, Akers RM, Huckle WR \& Forsten-Williams K 2007 Autocrine production of insulin-like growth factor-I (IGF-I) affects paracellular transport across epithelial cells in vitro. Cell Communication and Adhesion 14 85-98. (https://doi.org/10.1080/15419060701463116)

Pérez CV, Sobarzo CM, Jacobo PV, Pellizzari EH, Cigorraga SB, Denduchis B \& Lustig L 2012 Loss of occludin expression and impairment of bloodtestis barrier permeability in rats with autoimmune orchitis: effect of interleukin 6 on Sertoli cell tight junctions. Biology of Reproduction 87 1-12. (https://doi.org/10.1095/biolreprod.112.101709)

Polette $M$, Mestdagt $M$, Bindels S, Nawrocki-Raby B, Hunziker W, Foidart J-M, Birembaut P \& Gilles C $2007 \beta$-Catenin and ZO-1: shuttle molecules involved in tumor invasion-associated epithelialmesenchymal transition processes. Cells Tissues Organs 185 61-65. (https://doi.org/10.1159/000101304)

Pozzi A \& Zent R 2010 ZO-1 and ZONAB interact to regulate proximal tubular cell differentiation. Journal of the American Society of Nephrology 21 388-390. (https://doi.org/10.1681/ASN.2010010061)

Qu F, Wang FF, Lu XE, Dong MY, Sheng JZ, Lv PP, Ding GL, Shi BW, Zhang D \& Huang HF 2010 Altered aquaporin expression in women 
with polycystic ovary syndrome: hyperandrogenism in follicular fluid inhibits aquaporin-9 in granulosa cells through the phosphatidylinosito 3-kinase pathway. Human Reproduction 25 1441-1450. (https://doi. org/10.1093/humrep/deq078)

Rachow S, Zorn-Kruppa M, Ohnemus U, Kirschner N, Vidal-y-Sy S, von den Driesch P, Börnchen C, Eberle J, Mildner M \& Vettorazzi E 2013 Occludin is involved in adhesion, apoptosis, differentiation and $\mathrm{Ca}$ 2+-homeostasis of human keratinocytes: implications for tumorigenesis. PLOS ONE 8 e55116. (https://doi.org/10.1371/journal.pone.0055116)

Rajashekhar G, Shivanna M, Kompella UB, Wang Y \& Srinivas SP 2014 Role of MMP-9 in the breakdown of barrier integrity of the corneal endothelium in response to TNF- $\alpha$. Experimental Eye Research 122 77-85. (https://doi.org/10.1016/j.exer.2014.03.004)

Rangel LB, Agarwal R, D'Souza T, Pizer ES, Alò PL, Lancaster WD, Gregoire L, Schwartz DR, Cho KR \& Morin PJ 2003a Tight junction proteins claudin-3 and claudin-4 are frequently overexpressed in ovarian cancer but not in ovarian cystadenomas. Clinical Cancer Research 9 2567-2575.

Rangel LB, Sherman-Baust CA, Wernyj RP, Schwartz DR, Cho KR \& Morin PJ 2003 b Characterization of novel human ovarian cancer-specific transcripts (HOSTs) identified by serial analysis of gene expression. Oncogene 22 7225-7232. (https://doi.org/10.1038/sj.onc.1207008)

Raviola G, Sagaties MJ \& Miller C 1987 Intercellular junctions between fibroblasts in connective tissues of the eye of macaque monkeys. A thin section and freeze fracture analysis. Investigative Ophthalmology and Visual Science 28 834-841.

Richards JS 1980 Maturation of ovarian follicles: actions and interactions of pituitary and ovarian hormones on follicular cell differentiation. Physiological Reviews $60 \quad 51-89 . \quad$ (https://doi.org/10.1152/ physrev.1980.60.1.51)

Rimon E, Sasson R, Dantes A, Land-Bracha A \& Amsterdam A 2004 Gonadotropin-induced gene regulation in human granulosa cells obtained from IVF patients: modulation of genes coding for growth factors and their receptors and genes involved in cancer and other diseases. International Journal of Oncology 24 1325-1338.

Rodewald M, Herr D, Fraser H, Hack G, Kreienberg R \& Wulff C 2007 Regulation of tight junction proteins occludin and claudin 5 in the primate ovary during the ovulatory cycle and after inhibition of vascular endothelial growth factor. Molecular Human Reproduction 13 781-789. (https://doi.org/10.1093/molehr/gam066)

Rodewald M, Herr D, Duncan WC, Fraser HM, Hack G, Konrad R, Gagsteiger F, Kreienberg R \& Wulff C 2009 Molecular mechanisms of ovarian hyperstimulation syndrome: paracrine reduction of endothelial claudin 5 by hCG in vitro is associated with increased endothelial permeability. Human Reproduction 24 1191-1199. (https://doi. org/10.1093/humrep/den479)

Rodgers RJ \& Irving-Rodgers HF 2010 Formation of the ovarian follicular antrum and follicular fluid. Biology of Reproduction 82 1021-1029. (https://doi.org/10.1095/biolreprod.109.082941)

Roh MH, Liu C-J, Laurinec S \& Margolis B 2002 The carboxyl terminus of zona occludens- 3 binds and recruits a mammalian homologue of discs lost to tight junctions. Journal of Biological Chemistry 277 27501-27509. (https://doi.org/10.1074/jbc.M201177200)

Romanov V, Whyard TC, Waltzer WC \& Gabig TG 2014 A claudin 3 and claudin 4-targeted Clostridium perfringens protoxin is selectively cytotoxic to PSA-producing prostate cancer cells. Cancer Letters 351 260-264. (https://doi.org/10.1016/j.canlet.2014.06.009)

Rübsam M, Broussard JA, Wickström SA, Nekrasova O, Green KJ \& Niessen CM 2017 Adherens junctions and desmosomes coordinate mechanics and signaling to orchestrate tissue morphogenesis and function: an evolutionary perspective. Cold Spring Harbor Perspectives in Biology (in press) a029207. (https://doi.org/10.1101/cshperspect. a029207)

Rüffer C \& Gerke V 2004 The C-terminal cytoplasmic tail of claudins 1 and 5 but not its PDZ-binding motif is required for apical localization at epithelial and endothelial tight junctions. European Journal of Cell Biology 83 135-144.

Rugg MS, Willis AC, Mukhopadhyay D, Hascall VC, Fries E, Fülöp C, Milner CM \& Day AJ 2005 Characterization of complexes formed between TSG-6 and inter- $\alpha$-inhibitor that act as intermediates in the covalent transfer of heavy chains onto hyaluronan. Journal of Biological Chemistry 280 25674-25686. (https://doi.org/10.1074/jbc. M501332200)
Saito H, Kaneko T, Takahashi T, Kawachiya S, Saito T \& Hiroi M 2000 Hyaluronan in follicular fluids and fertilization of oocytes. Fertility and Sterility 74 1148-1152. (https://doi.org/10.1016/S0015-0282(00)01586-7)

Saitou M, Furuse M, Sasaki H, Schulzke J-D, Fromm M, Takano H, Noda T \& Tsukita S 2000 Complex phenotype of mice lacking occludin, a component of tight junction strands. Molecular Biology of the Cell 11 4131-4142. (https://doi.org/10.1091/mbc.11.12.4131)

Sales AD, Duarte AB, Santos RR, Alves KA, Lima LF, Rodrigues GQ, Brito IR, Lobo CH, Bruno JB, Locatelli Y et al. 2016 Modulation of aquaporins 3 and 9 after exposure of ovine ovarian tissue to cryoprotectants followed by in vitro culture. Cell and Tissue Research 365 415-424. (https://doi. org/10.1007/s00441-016-2384-z)

Santin AD, Cané S, Bellone S, Palmieri M, Siegel ER, Thomas M, Roman JJ, Burnett A, Cannon MJ \& Pecorelli S 2005 Treatment of chemotherapyresistant human ovarian cancer xenografts in CB-17/SCID mice by intraperitoneal administration of Clostridium perfringens enterotoxin. Cancer Research 65 4334-4342. (https://doi.org/10.1158/0008-5472. CAN-04-3472)

Schoenfelder M \& Einspanier R 2003 Expression of hyaluronan synthases and corresponding hyaluronan receptors is differentially regulated during oocyte maturation in cattle. Biology of Reproduction 69 269-277. (https://doi.org/10.1095/biolreprod.102.011577)

Schossleitner K, Rauscher S, Gröger M, Friedl HP, Finsterwalder R, Habertheuer A, Sibilia M, Brostjan C, Födinger D \& Citi S 2016 Evidence that cingulin regulates endothelial barrier function in vitro and in vivo. Arteriosclerosis, Thrombosis, and Vascular Biology 36 647-654. (https://doi.org/10.1161/ATVBAHA.115.307032)

Schulzke J, Gitter A, Mankertz J, Spiegel S, Seidler U, Amasheh S, Saitou M, Tsukita S \& Fromm M 2005 Epithelial transport and barrier function in occludin-deficient mice. Biochimica et Biophysica Acta 1669 34-42. (https://doi.org/10.1016/j.bbamem.2005.01.008)

Schuster MK, Schmierer B, Shkumatava A \& Kuchler K 2004 Activin A and follicle-stimulating hormone control tight junctions in avian granulosa cells by regulating occludin expression. Biology of Reproduction 70 1493-1499. (https://doi.org/10.1095/biolreprod.103.024331)

Schütz LF, Schreiber NB, Gilliam JN, Cortinovis C, Totty ML, Caloni F, Evans JR \& Spicer LJ 2016 Changes in fibroblast growth factor 9 mRNA in granulosa and theca cells during ovarian follicular growth in dairy cattle. Journal of Dairy Science 99 9143-9151. (https://doi.org/10.3168/ jds.2015-10667)

Scotti L, Abramovich D, Pascuali N, Irusta G, Meresman G, Tesone M \& Parborell F 2014a Local VEGF inhibition prevents ovarian alterations associated with ovarian hyperstimulation syndrome. Journal of Steroid Biochemistry and Molecular Biology 144 392-401. (https://doi. org/10.1016/j.jsbmb.2014.08.013)

Scotti L, Parborell F, Irusta G, De Zuñiga I, Bisioli C, Pettorossi H, Tesone M \& Abramovich D $2014 b$ Platelet-derived growth factor BB and DD and angiopoietin1 are altered in follicular fluid from polycystic ovary syndrome patients. Molecular Reproduction and Development 81 748-756. (https://doi.org/10.1002/mrd.22343)

Shalgi R, Kraicer P, Rimon A, Pinto M \& Soferman N 1973 Proteins of human follicular fluid: the blood-follicle barrier. Fertility and Sterility $\mathbf{2 4}$ 429-434. (https://doi.org/10.1016/S0015-0282(16)39730-8)

Shen Z-Y, Zhang J, Song H-L \& Zheng W-P 2013 Bone-marrow mesenchymal stem cells reduce rat intestinal ischemia-reperfusion injury, ZO-1 downregulation and tight junction disruption via a TNF- $\alpha$-regulated mechanism. World Journal of Gastroenterology 19 3583-3595. (https://doi.org/10.3748/wjg.v19.i23.3583)

Silva J, Hamel M, Sahmi M \& Price C 2006 Control of oestradiol secretion and of cytochrome $\mathrm{P} 450$ aromatase messenger ribonucleic acid accumulation by FSH involves different intracellular pathways in oestrogenic bovine granulosa cells in vitro. Reproduction 132 909-917. (https://doi.org/10.1530/REP-06-0058)

Singer KL, Stevenson BR, Woo PL \& Firestone GL 1994 Relationship of serine/threonine phosphorylation/dephosphorylation signaling to glucocorticoid regulation of tight junction permeability and ZO-1 distribution in nontransformed mammary epithelial cells. Journal of Biological Chemistry $26916108-16115$.

Siu MK \& Cheng CY 2012 The blood-follicle barrier (BFB) in disease and in ovarian function. Advances in Experimental Medicine and Biology 763 186-192.

Skowronski MT, Kwon T-H \& Nielsen S 2009 Immunolocalization of aquaporin 1,5, and 9 in the female pig reproductive system. Journal of 
Histochemistry and Cytochemistry 57 61-67. (https://doi.org/10.1369/ jhc.2008.952499)

Soini Y \& Talvensaari-Mattila A 2006 Expression of claudins 1, 4, 5, and 7 in ovarian tumors of diverse types. International Journal of Gynecological Pathology 25 330-335. (https://doi.org/10.1097/01. pgp.0000215298.38114.cc)

Song H-L, Lv S \& Liu P 2009 The roles of tumor necrosis factor-alpha in colon tight junction protein expression and intestinal mucosa structure in a mouse model of acute liver failure. BMC Gastroenterology 970. (https://doi.org/10.1186/1471-230X-9-70)

Spadaro D, Tapia R, Pulimeno P \& Citi S 2012 The control of gene expression and cell proliferation by the epithelial apical junctional complex. Essays in Biochemistry 53 83-93. (https://doi.org/10.1042/bse0530083)

Spicer LJ 2004 Proteolytic degradation of insulin-like growth factor binding proteins by ovarian follicles: a control mechanism for selection of dominant follicles. Biology of Reproduction 70 1223-1230. (https://doi. org/10.1095/biolreprod.103.021006)

Spoerri P, Afzal A, Li CS, Shaw L, Cai J, Pan H, Boulton M \& Grant M 2006 Effects of VEGFR-1, VEGFR-2, and IGF-IR hammerhead ribozymes on glucose-mediated tight junction expression in cultured human retinal endothelial cells. Molecular Vision 1232.

Stevenson BR, Siliciano JD, Mooseker MS \& Goodenough DA 1986 Identification of ZO-1: a high molecular weight polypeptide associated with the tight junction (zonula occludens) in a variety of epithelia. Journal of Cell Biology 103 755-766. (https://doi.org/10.1083/ jcb.103.3.755)

Stevenson BR, Heintzelman M, Anderson JM, Citi S \& Mooseker MS 1989 ZO-1 and cingulin: tight junction proteins with distinct identities and localizations. American Journal of Physiology: Cell Physiology 257 C621-C628. (https://doi.org/10.1152/ajpcell.1989.257.4.C621)

Sugawara T, Iwamoto N, Akashi M, Kojima T, Hisatsune J, Sugai M \& Furuse M 2013 Tight junction dysfunction in the stratum granulosum leads to aberrant stratum corneum barrier function in claudin-1deficient mice. Journal of Dermatological Science $\mathbf{7 0} 12-18$. (https://doi. org/10.1016/j.jdermsci.2013.01.002)

Sun GW, Kobayashi H \& Terao T 1999 Expression of link protein during mouse follicular development. Journal of Histochemistry and Cytochemistry $\mathbf{4 7}$ 1433-1442. (https://doi.org/10.1177/002215549904701109)

Sun GW, Kobayashi H, Suzuki M, Kanayama N \& Terao T 2003 Folliclestimulating hormone and insulin-like growth factor I synergistically induce up-regulation of cartilage link protein (Crtl1) via activation of phosphatidylinositol-dependent kinase/Akt in rat granulosa cells. Endocrinology $\mathbf{1 4 4}$ 793-801. (https://doi.org/10.1210/en.2002220900)

Sun C, Yi T, Song X, Li S, Qi X, Chen X, Lin H, He X, Li Z, Wei Y \& Zhao X 2011 Efficient inhibition of ovarian cancer by short hairpin RNA targeting claudin-3. Oncology Reports 26 193-200. (https://doi.org/10.3892/ or.2011.1275)

Sun J, Wang X, Li C \& Mao B 2015 Xenopus Claudin-6 is required for embryonic pronephros morphogenesis and terminal differentiation. Biochemical and Biophysical Research Communications 462 178-183. (https://doi.org/10.1016/j.bbrc.2015.04.065)

Suzuki T 2013 Regulation of intestinal epithelial permeability by tight junctions. Cellular and Molecular Life Sciences 70 631-659. (https://doi. org/10.1007/s00018-012-1070-x)

Tamura A, Kitano Y, Hata M, Katsuno T, Moriwaki K, Sasaki H, Hayashi $H$, Suzuki Y, Noda T, Furuse M et al. 2008 Megaintestine in claudin15-deficient mice. Gastroenterology 134 523-534. (https://doi. org/10.1053/j.gastro.2007.11.040)

Thoroddsen A, Dahm-Kähler P, Lind AK, Weijdegård B, Lindenthal B, Müller J \& Brännström M 2011 The water permeability channels aquaporins 1-4 are differentially expressed in granulosa and theca cells of the preovulatory follicle during precise stages of human ovulation. Journal of Clinical Endocrinology and Metabolism 96 1021-1028. (https://doi.org/10.1210/jc.2010-2545)

Tian Y, Gawlak G, Tian X, Shah AS, Sarich N, Citi S \& Birukova AA 2016 Role of cingulin in agonist-induced vascular endothelial permeability. Journal of Biological Chemistry $29123681-23692 . \quad$ (https://doi. org/10.1074/jbc.M116.720763)

Tobioka H, Isomura H, Kokai Y, Tokunaga Y, Yamaguchi J \& Sawada N 2004 Occludin expression decreases with the progression of human endometrial carcinoma. Human Pathology 35 159-164. (https://doi. org/10.1016/j.humpath.2003.09.013)
Tokuda S \& Furuse M 2015 Claudin-2 knockout by TALEN-mediated gene targeting in MDCK cells: claudin-2 independently determines the leaky property of tight junctions in MDCK cells. PLOS ONE 10 e0119869. (https://doi.org/10.1371/journal.pone.0119869)

Toshimori K \& Ōura C 1982 Cellular interconnections in the young mouse ovary. Cell and Tissue Research 224 383-395. (https://doi.org/10.1007/ BF00216881)

Umeda K, Matsui T, Nakayama M, Furuse K, Sasaki H, Furuse M \& Tsukita S 2004 Establishment and characterization of cultured epithelial cells lacking expression of ZO-1. Journal of Biological Chemistry 279 44785-44794. (https://doi.org/10.1074/jbc.M406563200)

Umeda K, Ikenouchi J, Katahira-Tayama S, Furuse K, Sasaki H, Nakayama M, Matsui T, Tsukita S, Furuse M \& Tsukita S 2006 ZO-1 and ZO-2 independently determine where claudins are polymerized in tightjunction strand formation. Cell 126 741-754. (https://doi.org/10.1016/j. cell.2006.06.043)

Underwood JL, Murphy CG, Chen J, Franse-Carman L, Wood I, Epstein DL \& Alvarado JA 1999 Glucocorticoids regulate transendothelial fluid flow resistance and formation of intercellular junctions. American Journal of Physiology: Cell Physiology 277 C330-C342. (https://doi.org/10.1152/ ajpcell.1999.277.2.C330)

van Baal JOAM, van Noorden CJF, Nieuwland R, Van de Vijver KK, Sturk A, van Driel WJ, Kenter GG \& Lok CAR 2017 Development of peritoneal carcinomatosis in epithelial ovarian cancer: a review. Journal of Histochemistry and Cytochemistry 66 67-83. (https://doi. org/10.1369/0022155417742897)

Van Itallie CM \& Anderson JM 1997 Occludin confers adhesiveness when expressed in fibroblasts. Journal of Cell Science 110 1113-1121.

Van Itallie CM \& Anderson JM 2006 Claudins and epithelial paracellular transport. Annual Review of Physiology 68 403-429. (https://doi. org/10.1146/annurev.physiol.68.040104.131404)

Van Itallie CM \& Anderson JM 2014 Architecture of tight junctions and principles of molecular composition. Seminars in Cell and Developmental Biology 36 157-165. (https://doi.org/10.1016/j. semcdb.2014.08.011)

Van Itallie CM, Fanning AS, Bridges A \& Anderson JM 2009 ZO-1 stabilizes the tight junction solute barrier through coupling to the perijunctional cytoskeleton. Molecular Biology of the Cell 20 3930-3940. (https://doi. org/10.1091/mbc.E09-04-0320)

Van Itallie CM, Gambling TM, Carson JL \& Anderson JM 2005 Palmitoylation of claudins is required for efficient tight-junction localization. Journal of Cell Science 118 1427-1436. (https://doi.org/10.1242/jcs.01735)

Walshe TE, Saint-Geniez M, Maharaj AS, Sekiyama E, Maldonado AE \& D'Amore PA 2009 TGF- $\beta$ is required for vascular barrier function, endothelial survival and homeostasis of the adult microvasculature. PLoS ONE 4 e5149. (https://doi.org/10.1371/journal.pone.0005149)

Winterhager E \& Kidder GM 2015 Gap junction connexins in female reproductive organs: implications for women's reproductive health. Human Reproduction Update 21 340-352. (https://doi.org/10.1093/ humupd/dmv007)

Wissing M, Kristensen S, Andersen C, Mikkelsen A, Høst T, Borup R \& Grøndahl M 2014 Identification of new ovulation-related genes in humans by comparing the transcriptome of granulosa cells before and after ovulation triggering in the same controlled ovarian stimulation cycle. Human Reproduction 29 997-1010. (https://doi.org/10.1093/ humrep/deu008)

Wittchen E, Haskins J \& Stevenson B 1999 Protein interactions at the tight junction. Actin has multiple binding partners, and ZO-1 forms independent complexes with ZO-2 and ZO-3. Journal of Biological Chemistry 274 35179-35185. (https://doi.org/10.1074/ jbc.274.49.35179)

Woad KJ \& Robinson RS 2016 Luteal angiogenesis and its control. Theriogenology $\mathbf{8 6} \quad 221-228$. (https://doi.org/10.1016/j. theriogenology.2016.04.035)

Wong V \& Gumbiner BM 1997 A synthetic peptide corresponding to the extracellular domain of occludin perturbs the tight junction permeability barrier. Journal of Cell Biology 136 399-409. (https://doi.org/10.1083/ jcb.136.2.399)

Wong CH, Mruk DD, Lui WY \& Cheng CY 2004 Regulation of blood-testis barrier dynamics: an in vivo study. Journal of Cell Science 117 783-798. (https://doi.org/10.1242/jcs.00900)

Woo PL, Cha HH, Singer KL \& Firestone GL 1996 Antagonistic regulation of tight junction dynamics by glucocorticoids and transforming growth 
factor-in mouse mammary epithelial cells. Journal of Biological Chemistry 271 404-412. (https://doi.org/10.1074/jbc.271.1.404)

Wu CY, Jhingory S \& Taneyhill LA 2011 The tight junction scaffolding protein cingulin regulates neural crest cell migration. Developmental Dynamics 240 2309-2323. (https://doi.org/10.1002/dvdy.22735)

Xu J, Kausalya PJ, Phua DC, Ali SM, Hossain Z \& Hunziker W 2008 Early embryonic lethality of mice lacking ZO-2, but not ZO-3, reveals critical and nonredundant roles for individual zonula occludens proteins in mammalian development. Molecular and Cellular Biology 28 1669-1678. (https://doi.org/10.1128/MCB.00891-07)

Xu J, Yang Y, Hao P \& Ding X 2015 Claudin 8 contributes to malignant proliferation in human osteosarcoma U2OS cells. Cancer Biotherapy and Radiopharmaceuticals 30 400-404. (https://doi.org/10.1089/ cbr.2015.1815)

Yano T, Matsui T, Tamura A, Uji M \& Tsukita S 2013 The association of microtubules with tight junctions is promoted by cingulin phosphorylation by AMPK. Journal of Cell Biology 203 605-614. (https:// doi.org/10.1083/jcb.201304194)

Yap AS, Gomez GA \& Parton RG 2015 Adherens junctions revisualized: Organizing cadherins as nanoassemblies. Developmental Cell 35 12-20. (https://doi.org/10.1016/j.devcel.2015.09.012)

Yeager M \& Harris AL 2007 Gap junction channel structure in the early 21st century: facts and fantasies. Current Opinion in Cell Biology 19 1-8. (https://doi.org/10.1016/j.ceb.2006.12.015)

Yoon CH, Kim MJ, Park MJ, Park IC, Hwang SG, An S, Choi YH, Yoon G \& Lee SJ 2010 Claudin-1 acts through c-Abl-protein kinase C $\delta$ (PKC $\delta$ ) signaling and has a causal role in the acquisition of invasive capacity in human liver cells. Journal of Biological Chemistry 285 226-233. (https:// doi.org/10.1074/jbc.M109.054189)

Yoshida K-I, Kanaoka S, Takai T, Uezato T, Miura N, Kajimura M \& Hishida A 2005 EGF rapidly translocates tight junction proteins from the cytoplasm to the cell-cell contact via protein kinase $\mathrm{C}$ activation in TMK-1 gastric cancer cells. Experimental Cell Research 309 397-409. (https://doi.org/10.1016/j.yexcr.2005.06.019)
Youakim A \& Ahdieh M 1999 Interferon- $\gamma$ decreases barrier function in T84 cells by reducing ZO-1 levels and disrupting apical actin. American Journal of Physiology: Gastrointestinal and Liver Physiology 276 G1279G1288. (https://doi.org/10.1152/ajpgi.1999.276.5.G1279)

Yu AS, McCarthy KM, Francis SA, McCormack JM, Lai J, Rogers RA, Lynch RD \& Schneeberger EE 2005 Knockdown of occludin expression leads to diverse phenotypic alterations in epithelial cells. American Journal of Physiology: Cell Physiology 288 C1231-1241. (https://doi. org/10.1152/ajpcell.00581.2004)

Zhang L, Schütz LF, Robinson CL, Totty ML \& Spicer LJ 2017 Evidence that gene expression of ovarian follicular tight junction proteins is regulated in vivo and in vitro in cattle. Journal of Animal Science 95 1313-1324. (https://doi.org/10.2527/jas.2016.0892)

Zhou H, Ohno N, Terada N, Saitoh S, Fujii Y \& Ohno S 2007 Involvement of follicular basement membrane and vascular endothelium in bloodfollicle barrier formation of mice revealed by 'in vivo cryotechnique'. Reproduction 134 307-317. (https://doi.org/10.1530/REP-07-0062)

Zhu Y \& Sundfeldt K 2007 Tight junction formation in epithelial ovarian adenocarcinoma. Acta Obstetrica et Gynecologicia Scandinavica 86 1011-1019 (https://doi.org/10.1080/00016340701463889)

Zhu Y, Maric J, Nilsson M, Brännström M, Janson PO \& Sundfeldt K 2004 Formation and barrier function of tight junctions in human ovarian surface epithelium. Biology of Reproduction 71 53-59. (https://doi. org/10.1095/biolreprod.103.022913)

Received 10 August 2017

First decision 15 September 2017

Revised manuscript received 11 January 2018

Accepted 26 January 2018 